Article

\title{
PGE Production in Southern Africa, Part I: Production and Market Trends
}

\author{
Lisa Thormann ${ }^{1}$, Benedikt Buchspies ${ }^{1, *}$, Charles Mbohwa ${ }^{2}$ and Martin Kaltschmitt ${ }^{1}$ \\ 1 Institute of Environmental Technology and Energy Economics (IUE), Hamburg University of \\ Technology (TUHH), Eissendorfer Str. 40, 21073 Hamburg, Germany; lisa.thormann@tuhh.de (L.T.); \\ kaltschmitt@tu-harburg.de (M.K.) \\ 2 Department of Quality and Operations Management, Faculty of Engineering and the Built Environment, \\ University of Johannesburg, Auckland Park Kingsway Campus, P.O. Box 524, Auckland Park, \\ 2006 Johannesburg, South Africa; cmbohwa@uj.ac.za \\ * Correspondence: benedikt.buchspies@tuhh.de; Tel.: +49-40-42878-3008
}

Received: 24 July 2017; Accepted: 14 November 2017; Published: 18 November 2017

\begin{abstract}
Platinum group elements (PGEs) are an important resource for many applications, such as automotive catalytic converters for vehicles, jewelry, electrical devices and as catalysts in the chemical and petroleum industries. At present, the greatest share of global PGE supply is extracted from the South African Bushveld Complex and from the Zimbabwean Great Dyke. In this context, this article provides a comprehensive summary of detailed mining data between 2010 and 2015 and discusses these in regard to the global PGE market. On the supply side, the data reveal that the production volumes as well as the ore grades fluctuated in recent years, while the mining and processing of economically less favorable Upper Group 2 (UG2) ore increased. The average head grade from 2010 to 2015 was $3.58 \mathrm{~g}$ 6E/t. In the long term, the ore grades decreased. On the market side, PGE prices and increasing (primary) production costs can be observed. On the market side, the demand for vehicles is expected to grow globally resulting in an increase in PGE demand. At the same time, secondary production is expected to increase and will eventually compete with primary production. These findings indicate challenging conditions for the Southern African PGE industry.
\end{abstract}

Keywords: platinum group elements (PGE); mineral resources; Southern Africa; Bushveld Complex; Great Dyke

\section{Introduction}

Several distinctive properties of platinum group elements (PGE) make them crucial to numerous industrial applications [1]. They are used in a broad variety of chemical processes and industrial products, including catalytic converters, jewelry, electrical devices and as catalysts in the chemical and petroleum industries. PGEs include platinum $(\mathrm{Pt})$, palladium $(\mathrm{Pd})$, rhodium $(\mathrm{Rh})$, ruthenium $(\mathrm{Ru})$, iridium (Ir), and osmium (Os) (Platinum group elements (PGE) occur together in nature (in combination with minor gold $(\mathrm{Au})$ ). The denominations 3E PGE, 4E PGE and 6E PGE refer to $\mathrm{Pt}+\mathrm{Pd}+\mathrm{Au}, \mathrm{Pt}$, $\mathrm{Pd}, \mathrm{Rh}+\mathrm{Au}$ and $\mathrm{Pt}+\mathrm{Pd}+\mathrm{Rh}+\mathrm{Ru}+\mathrm{Ir}+\mathrm{Au}$, respectively). These metals share several useful characteristics including their ability to catalyze chemical reactions, to resist corrosion, and their high conductivity, density and melting point [2].

PGEs are therefore used in multiple applications in:

1. the automotive industry as catalytic converters (for flue gas treatment to meet the given emission standards) and in fuel cells;

2. the chemical industry as catalysts for the production of silicones, fertilizers, explosives, and nitric acid, etc.; 
3. the petrochemical industry as catalysts;

4. the electronics industry as components in hard disk drives, liquid-crystal and flat-panel displays, etc.;

5. the glass manufacturing industry for the production of fiberglass, etc.;

6. for the production of jewelry and many other products [1].

Due to their unique characteristics (e.g., PGEs have the appearance of silver, but are not oxidizing and are harder than gold), and hence their lack of substitutes, their relevance to many industry sectors, and the limited number of places where they are mined, several governments such as the EU (on behalf of its member states), Japan and the US have labeled PGEs as "critical" materials [3-6].

PGEs are relatively rare elements in the Earth's upper crust. On average, the upper crust contains about $0.0005 \mathrm{ppm}$ of $\mathrm{Pt}$ [1]. So far, only very few deposits are known that contain a relatively high concentration of PGEs [7]. Most of the global PGE resources are concentrated in magmatic ore deposits [8]. Globules concentrating metals such as $\mathrm{Cu}, \mathrm{Ni}$ and PGEs were formed in magmatic processes. Thus, the majority of magmatic $\mathrm{Cu}$-Ni-PGE deposits can be found together with volcanic and plutonic rocks. The latter were formed when large volumes of mafic magma rose from the earth's mantle into the earth's crust [1].

At present, the economically mineable deposits are located in the Bushveld Complex in South Africa, in the Noril'sk-Talnakh field in Russia, in the Great Dyke in Zimbabwe, in the Stillwater Complex in the United States as well as in the Sudbury Basin in Canada [9,10]. Today Southern Africa presents by far the largest producer of PGEs in the world [11]. The terminology Southern Africa is used to denote South Africa and Zimbabwe. The PGE industry in both countries is strongly connected and thus considered in this article as an entity. Thus, the South African and Zimbabwean PGE industries are essential to cover today's global PGE demand. In 2014, the world mine production of Pt $(146,000 \mathrm{~kg})$ was mainly from the United States $(3660 \mathrm{~kg})$, Canada $(8500 \mathrm{~kg})$, Zimbabwe $(13,000 \mathrm{~kg})$, Russia $(23,000 \mathrm{~kg})$ and South Africa $(93,991 \mathrm{~kg})[11]$.

In 2015, the PGE industry contributed around $1.7 \%$ to the South African GDP and is an important source of income and an important economic sector [12]. In 2013, nearly 200,000 people were employed in the PGE mining industry [13].

A comprehensive and up-to-date overview of the recent production data of PGEs in Southern Africa is not available at present. Relevant publications by Mudd et al. in 2010 and $2012[9,14,15]$ are already outdated due to the continuous change of the PGE mining industry, whereas the information provided by other organizations, e.g., United States Geological Survey and British Geological Survey, cover PGE data that are mainly country-based and no differentiation is made between participating companies or between mines $[11,16]$. The publication of PGE mining and production data is essential and indispensable in regard to a broad variety of aspects. This article provides data that allow further studies, including economic assessments, environmental assessments (e.g., impacts of mining of PGEs), etc. Without a comprehensive overview of the PGE market in Southern Africa, no such assessments can be conducted.

Therefore, this article aims to provide a synopsis of recent trends, i.e., from 2010 to 2015, in PGE mining in Southern Africa and to discuss this in the context of the global PGE market. Furthermore, a projection of future demand, primary production and recycling is given. At first, the PGE market conditions are explained by providing insights into demand, supply and price developments. In a second step, a brief overview of ore geology and the PGE industry in Southern Africa is provided. Subsequently, a detailed summary of recent PGE production statistics is presented and discussed in the context of the previously outlined market environment. The data collected and reviewed for this step is acquired from PGE producers in South Africa and Zimbabwe. The most important aspects, such as the production quantities of different metals, head grades, hoisted material, type of ore that is mined, prill splits, etc., are gathered for individual mines and discussed in the global context. This presents the most detailed and up-to-date description of PGE mining data currently available for Southern 
Africa. A discussion of the environmental aspects of PGE production in Southern Africa based thereon is presented in part II of this article (see part II [17]).

\section{PGE Demand, Supply and Price Developments}

The Southern African PGE industry is embedded in a complex market that is mainly influenced by $[18,19]$ :

- On the demand side, the economic growth in many countries (e.g., China) that has increased the number of participants in the PGE market and resulted in an increase in demand for a broad variety of applications.

- On the supply side, secondary producers who started entering the market about two decades ago, providing an alternative to primary PGE production.

In this context, the worldwide use and production of PGEs as well as the global price developments for selected PGEs are given in the following to display the global interdependencies of the Southern African mining industry.

\subsection{Use and Demand}

Figure 1 shows the global demand of PGEs per industry sector for the last decades. For Pt, Pd and $\mathrm{Rh}$ the largest consumers are the automotive industry and the jewelry market. In the case of $\mathrm{Pt}$, the catalytic converter market drives the increase in demand, whereas the demand for investment and jewelry decreased. In 2014, the Pt demand for catalytic converters accounted for $40 \%$ of total Pt demand and $65 \%$ of industrial Pt demand.

Europe and North America are the most important markets due to the use of $\mathrm{Pt}$ in automotive exhaust catalysts. The demand for jewelry mostly originates from Asia [18,20]. In the past five years, market behavior, especially in China, has changed; the demand for jewelry decreased in line with prices as decreasing prices resulted in the perception of consumers that Pt is not such a solid investment as expected [20]. Before that, the demand for jewelry increased when prices decreased and vice versa. The demand of the petroleum industry depends on the build-up of production capacities, whereas the demand of the electronic industry is linked to the demand for consumer goods. In the years following the August 2007 financial crisis, the increase in total demand was largely met by an increase in recycling [21,22].

The demand for Pd is also dominated by the automotive market. Pd superseded $\mathrm{Pt}$ in three-way catalysts in recent years and is gradually taking over the market share of $\mathrm{Pt}$ in the catalytic converter market. Pd is superseded by other materials in the case of electric consumer goods [21].

The demand for Pt and Pd is expected to grow in the upcoming decade. The demand increase originated from the demand of the automotive industry. In many countries with growing markets, such as India, Russia, China and Brazil, stricter legislation regarding exhaust gas emissions from vehicles will most likely be introduced resulting in an increase in demand for exhaust gas catalysts [20,23,24]. The estimated extent of growth varies among experts; Jollie [25] predicts compound annual growth rates (CAGRs) of total Pt and Pd demand of 1.0 and 1.1\%/a for Pt and Pd, respectively [25]. Based on the reported demand, production and recycling estimates for the period from 2017 to 2021 by Jollie [20], CAGRs of 0.4, 1.7 and 3.3\% / a for primary production, recycling and demand of $\mathrm{Pt}$ can be derived. Zhang et al. [23] predict CAGRs of automotive PGE demand of 0.6 and 3.9\%/a for Pt and Pd, respectively, for the period up to 2030 [23]. A contradictory trend can be seen in the automotive market (primarily) in the United States, China and Europe that is experiencing a further change from vehicles with internal combustion engines to electric vehicles [26-28]. At present, electric vehicles typically use lithium ion batteries (and no automotive exhaust catalysts are needed) [28]. Hence, an increase in electric vehicles reduces the demand for PGEs [29].

In the case of $\mathrm{Ru}$ and $\mathrm{Ir}$, the highest demand originates from the electronic industry. Ir is used to produce light-emitting diodes (LEDs) for displays and touchscreens $[30,31]$. The production of these 
products resulted in the sharp increase in demand (and price) that can be observed in 2010 [32]. The use of cheaper substitutes resulted in a decrease in demand and a resulting price drop. Likewise, the demand for Ru decreased in recent years due to the substitution of 'traditional' hard disks by flash drives [33,34]. Rh, as well as Pt and Pd, are mainly used by the automotive industry, accounting for more than three quarters of total demand [35]. Beside this, Rh is used in the glass industry [36]. In this case, the Rh demand of glass manufacturers fluctuates due to the substitutability of $\mathrm{Rh}$ and $\mathrm{Pt}$ in glass manufacturing. The demand of $\mathrm{Rh}$ is predicted to grow by $2.2 \% / \mathrm{a}$ until 2030 [23].

This selection of examples shows that the demand of all PGEs strongly depends on world economic conditions, either related to global sales of vehicles or related to the demand for electronic consumer products. In all cases, the industry substitutes a certain PGE by cheaper alternatives, if available [34].

\subsection{Primary and Secondary Production}

On a global scale, PGEs are obtained from primary sources (i.e., ore mined, e.g., in South Africa, Russia and Canada) and from secondary sources (i.e., recycled material). Both sources are discussed in detail below.

Primary sources. In 2014, most of the global primary Pt and Pd produced came from South Africa (Pt ca. 64\%, Pd ca. 30\%) and Russia (Pt ca. 16\%, Pd ca. 43\%) [11]. The global Pt production decreased from about $193 \mathrm{t}$ in 2010 to approx. $146 \mathrm{t}$ in 2014; this represents a decrease of roughly $25 \%$ (Figure 1). Similar to this development, the global Pd production also declined from $208 \mathrm{t}(2010)$ to $193 \mathrm{t}$ (2014), amounting to a decrease of about $8 \%$. In 2014, the main share of other PGE production (namely Ir, Os, Rh, and $\mathrm{Ru}$ ) also produced by South Africa and Russia totaled $38 \mathrm{t}$ and $12 \mathrm{t}$, respectively. In South Africa, base metals, i.e., $\mathrm{Ni}$ and $\mathrm{Cu}$, are mined as by-products of most mines or in rare cases as the principal metals that are targeted. In 2015, South Africa supplied 2.5\% and less than $0.5 \%$ of the global primary supply of $\mathrm{Ni}$ and $\mathrm{Cu}$, respectively [37,38].

Historically, annual PGE production has increased throughout the 20th century [9]. The overall trend of PGE production per country shows that the production rates increased until 2004/06 and started to decrease since then until 2014 (Figure 2). The decline observed throughout these years can mostly be attributed to a decrease in PGE production in South Africa and to decreasing demand. Production volumes were severely affected by recent strikes in South Africa. Production losses of 34 and $12 \mathrm{t} \mathrm{Pt}$ were a consequence of the strikes in 2012 and 2014, respectively [11]. The strike in 2012 resulted in the termination of thousands of employment contracts of miners [39]. The decrease in supply from South African mines could not be eased by an increase in production elsewhere, mainly due to low Pt to Pd ratios found in other PGE mines around the world. The financial crisis in August 2007 affected the global demand for Pt. The declining demand for Pt resulted in a decrease in the Southern African production and, to a lesser extent, globally [29]. These trends emphasize the correlation of a supply that is dependent on very few primary sources and global commodity markets. The global demand is hence dependent on few providing countries and strongly influenced by the political setting in the few supplying countries. In return, the PGE-producing countries depend highly on global market conditions.

Secondary sources. PGEs from secondary sources gained importance in the last two decades. At present, the most important secondary PGE sources are automotive catalytic converters for $\mathrm{Pt}$ and Pd, as well as jewelry for Pd. For example, in 2014 more than $100 \mathrm{t}$ of PGE were recovered from catalytic converters: about $55 \mathrm{t}$ of PGEs in the US, $33 \mathrm{t}$ in Europe, $13 \mathrm{t}$ in Japan, and $2 \mathrm{t}$ in China [40]. 


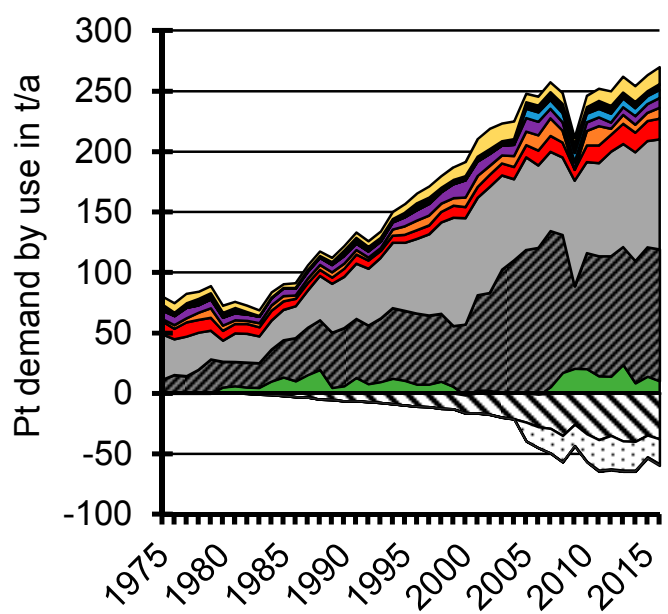

(a)

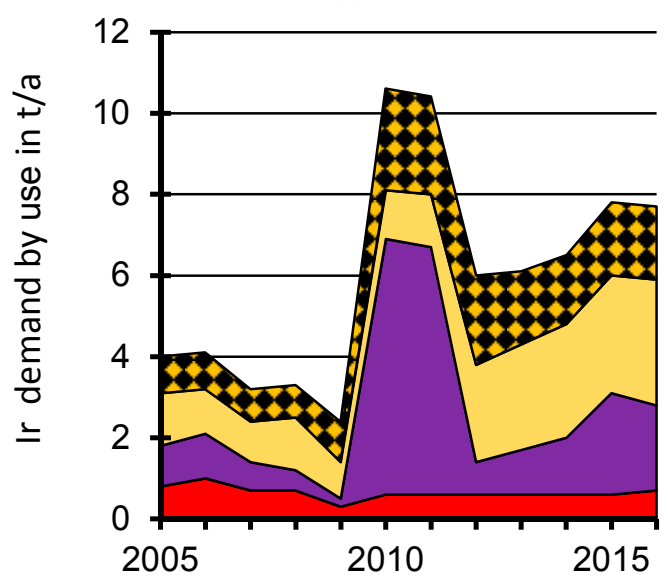

(c)

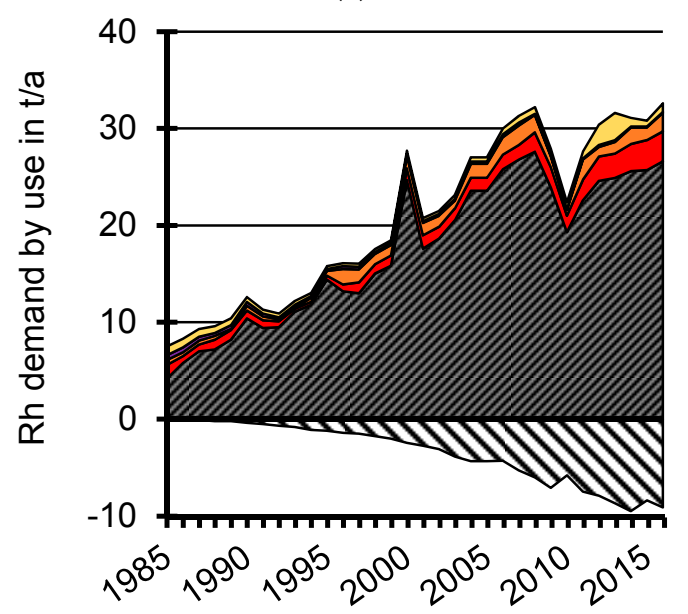

(e)

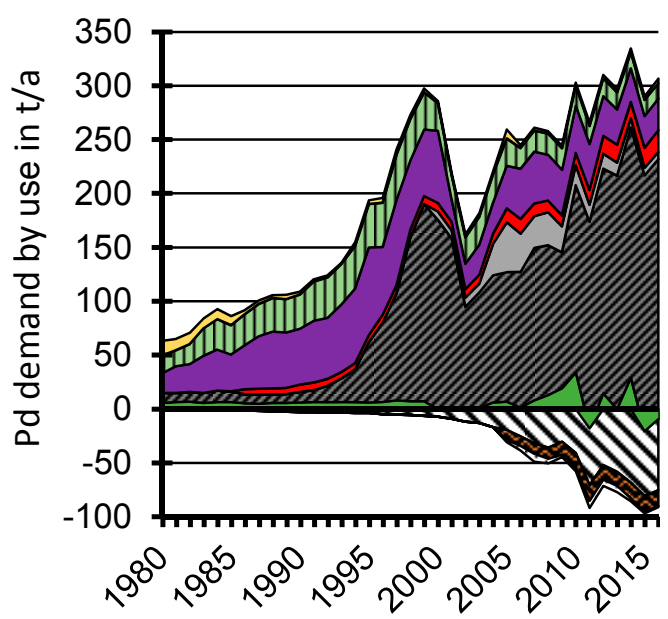

(b)

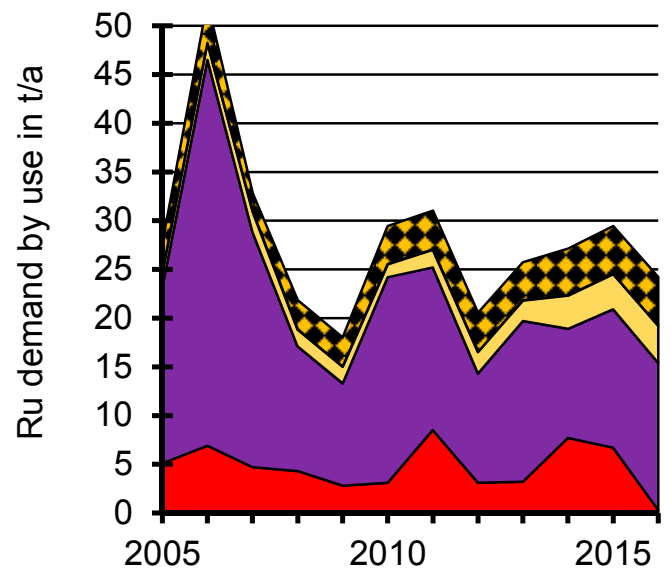

(d)

$\square$ Other

- Petroleum

$\square$ Medical \& Biomedical

$\square$ Electrical

$\square$ Glass

$\square$ Chemical

$\square$ Jewelry

口 Automotive exhaust gas catalytic converter - Electrochemical

Recycling: Electrical

๑Recycling: Jewelry

vecycling: Autocatalyst

Investment

๓Dental

Figure 1. Global Pt (a), Pd (b), Ir (c), Ru (d) and Rh (e) demand from 1975, 1980, 2005 and 1985, respectively, to 2016 (before 1980, investment demand for Pt is contained in our "Other" estimates; before 2005, "Jewelry" and "Electrical" demand for Pt is the net of recycling, "Medical \& Biomedical" is contained in "Other"; before 1986, the Pd demand of the chemical industry is contained in "Other" estimates) [18,41]. 


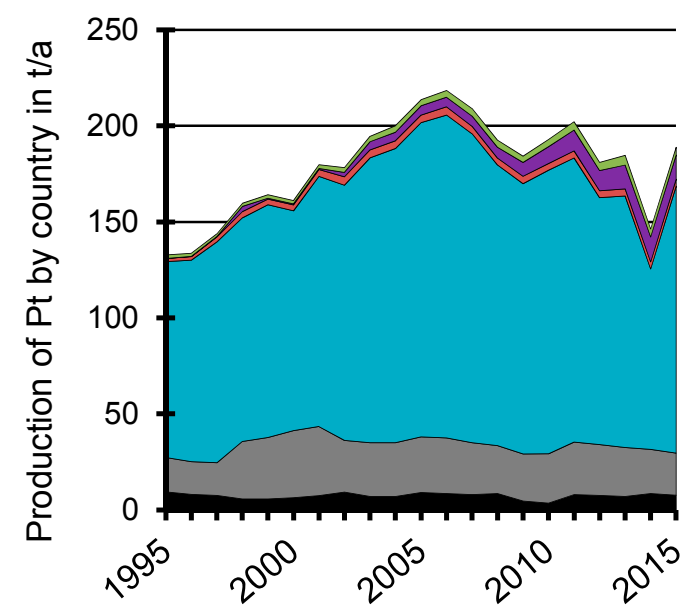

(a)

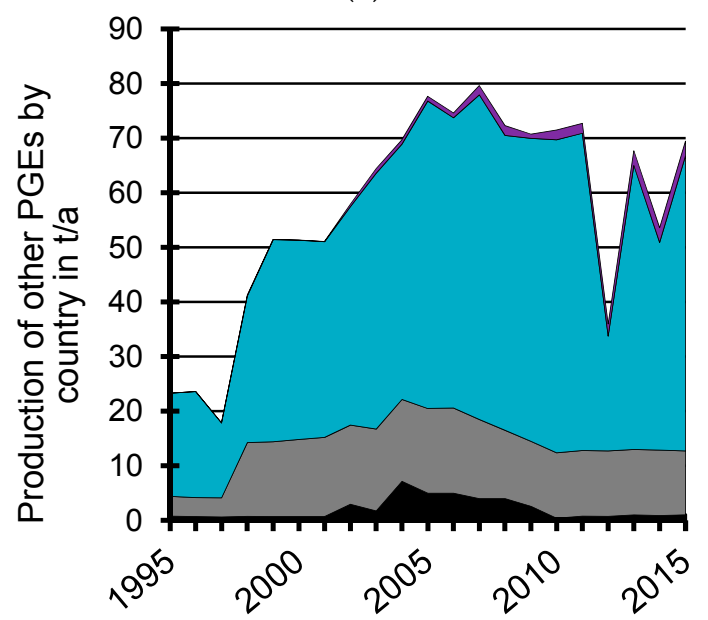

(c)

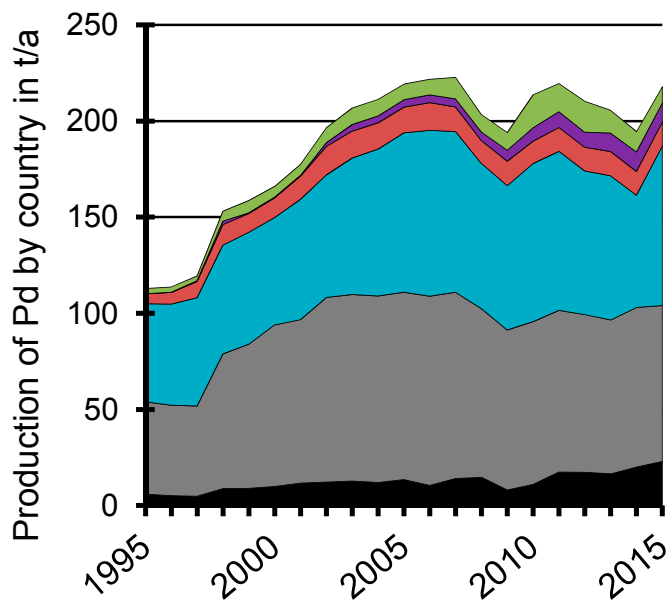

(b)

Figure 2. Primary production of Pt (a), Pd (b) and other PGEs (c) by selected countries [11].

\subsection{Price Developments}

The price of Pt in US Dollars (US\$) increased relatively constantly from 1998 to 2011 (Table S1). Afterwards, a continuing downward trend started. In 2016, the price reached $32.1 \mathrm{US} \$ / \mathrm{g}$. This represents a decrease by $42 \%$ compared to the peak price in 2012. In general, the Pt price follows the gold price and thereby, more or less the global economic development [11,19]. This effect can be seen in the impact on Pt prices following the financial crisis in August 2007.

The price of Pd also started to increase slightly in the early 2000s. Since 2009, the price increased to a larger extent each year until it peaked in 2014. Mainly two effects have influenced this price development:

- One price-influencing parameter was the continuing political crisis in the Ukraine and accordingly, the concern that economic sanctions might be enforced against Russia [11]. Currently, Russia is globally the main producer of Pd (Figure 2).

- The prices were also influenced by the workers' strikes in South Africa (see Section 2.2), cf. [42,43].

Due to the exchange rate between the US\$ and the South African Rand (ZAR), the Pt prices in ZAR steadily increased, while prices in US\$ decreased after the peak in 2011 (Table S1). 


\section{PGE Deposits in Southern Africa}

The occurrence and distribution of terrestrial PGE deposits are closely related to the occurrence of igneous provinces [44]. In the sub-continental lithospheric mantle, sulfides are the most common carriers of PGEs. The PGE content of mantle sulfides is typically three orders of magnitude higher than the concentration in bulk rock mantle peridotite [45]. This can be explained by the tendency of PGEs to concentrate in sulfide melting [46]. Therefore, the behavior of sulfur during mantle melting controls PGE distribution and concentration. Furthermore, the partition coefficient differs among PGEs ( $\mathrm{Au} \sim \mathrm{Os} \sim \mathrm{Ir} \sim \mathrm{Ru}<\mathrm{Pt}<\mathrm{Rh}<\mathrm{Pd}$ ) resulting in varying tendencies to concentrate in specific minerals $[47,48]$. The PGE deposits in Southern Africa are hosted by layered mafic and ultramafic intrusions that represent solidified open-system magma chambers [44]. The mafic-ultramafic layered intrusion located in Southern Africa, named Bushveld Complex, is the largest known of its type [9]. The Great Dyke in Zimbabwe is a layered intrusion that contains the second large reserve of PGE worldwide [49]. At present, five PGE deposits are economically exploited: (1) the Merensky reef, (2) the Upper Group 2 (UG2) chromitite layer, (3) the Platreef, (4) the Main Sulfide Zone (MSZ), and (5) The Nkomati Nickel Deposit [50].

\subsection{The Bushveld Complex}

The South African Bushveld Complex contains about 63,260 $t$ of the global PGE mineral resources (90,733 t PGEs (4E)) [9]. It is about $9 \mathrm{~km}$ thick and extends about $450 \mathrm{~km}$ East-West and $350 \mathrm{~km}$ North-South [50,51]. The concentration of PGEs ranges from $3 \mathrm{~g} / \mathrm{t}$ to $10 \mathrm{~g} / \mathrm{t}$ in ore $[9,14,44,52-54]$ (Prill splits for each section are reported in Table S2). The Bushveld Complex is the only location where reef-type PGE deposits (Merensky and UG2 reef type) and contact-type Cu-Ni-PGE deposits are mined. Apart from PGEs, notable quantities of $\mathrm{Ni}, \mathrm{Cu}, \mathrm{Co}, \mathrm{Cr}$, $\mathrm{Au}$ and small amounts of $\mathrm{Ag}$, $\mathrm{Sb}, \mathrm{Bi}$, and $\mathrm{Te}$ can be recovered [55-61].

The geographic subdivision of the Bushveld Complex into three limbs is based on the outcrop distribution of mafic and ultramafic rocks that make up the Rustenburg Layered Suite of the Bushveld Complex. The mines are located within these rocks. (Figure 3). The Eastern Limb can be further subdivided into the North-Eastern and South-Eastern Limbs separated by the Steelpoort lineament. Each limb is characterized by the type of reef that it contains. The Eastern and Western Limbs contain both Merensky and UG2 type reefs, while the Northern Limb contains only the Platreef type $[9,50]$. The stratigraphy of the Bushveld Complex is divided into the Marginal, Lower, Critical, Main and Upper Zones. The Critical Zone is subdivided into the Lower Critical Zone and Upper Critical Zone. The Lower Critical Zone mostly consists of bronzitites, chromitites and harzburgites, whereas the Upper Critical Zone consists of norites, bronzites, chromitite, harzburgite and anorthosites [62]. The Merensky reef and UG2 can be found in the Upper Critical Zone. The concentration of PGE ranges from $0.2 \mathrm{~g} / \mathrm{t}$ to $2.1 \mathrm{~g} / \mathrm{t}$, from $0.9 \mathrm{~g} / \mathrm{t}$ to $5.5 \mathrm{~g} / \mathrm{t}$ and from $1.2 \mathrm{~g} / \mathrm{t}$ to $8 \mathrm{~g} / \mathrm{t}$ in the Lower Group chromite reefs of the Lower Critical Zone, the Middle Group chromitite reefs of the Lower and Upper Critical Zone and the Upper Group chromite reefs in the Upper Critical Zone, respectively [44].

The Merensky reef. The Merensky reef consists of pegmatoidalmelanorite $(70 \%-90 \%$ orthopyroxene) that contains base-metal sulfides and up to four chromite seams confining the pegmatoid layer $[45,63,64]$. The melanorite is about $10 \mathrm{~cm}$ to $30 \mathrm{~cm}$ thick, whereas the chromite seams measure $1 \mathrm{~cm}$ to $3 \mathrm{~cm}$ [45]. PGEs occur in Pt-Fe alloys, Pd alloys, Pt-arsenides, laurite, Pt-Pd sulfides and Pt-Pd tellurides [44]. The distribution of these mineral groups is heterogeneous throughout the Bushveld Complex: In some sections, Pt-Pd alloys dominate, whereas in others, Pt-Pd sulfides or Pt-Pd tellurides constitute the major share of PGE-bearing minerals. The upper and lower chromitite seams differ in composition: The lower seam comprises more than $48 \%$ (by area) of Pt-Pd sulfides, whereas the upper seam is dominated by Pt-Fe alloys (>45\%) [45]. The PGE concentration is highest in the upper part of the layer [65]. The occurrence of PGE elements is closely linked to the presence of Fe-Ni-Cu sulfides [44]. The PGE-bearing minerals occur enclosed in base-metal sulfides, along grain boundaries and the contact zones of sulfides and silicates or oxides [44,63]: in $38 \%$ to $97 \%$ of occurrences, 
PGE-bearing minerals were found to be enclosed in or attached to base metal sulfides; the remainder are enclosed in silicates $[64,66]$. The most commonly occurring base metal sulfides are pyrrhotite, pentlandite and chalcopyrite, with $\sim 40 \%, \sim 30 \%$ and $\sim 15 \%$, respectively $[65,66]$. Orthopyroxene, plagioclase feldspar, clinopyroxene and phlogopite account for $\sim 60 \%, \sim 20 \%, \sim 15 \%$ and $\sim 5 \%$ of the silicate minerals, respectively. The most common interspersed secondary minerals are talc, serpentine, chlorite and magnetite [66].

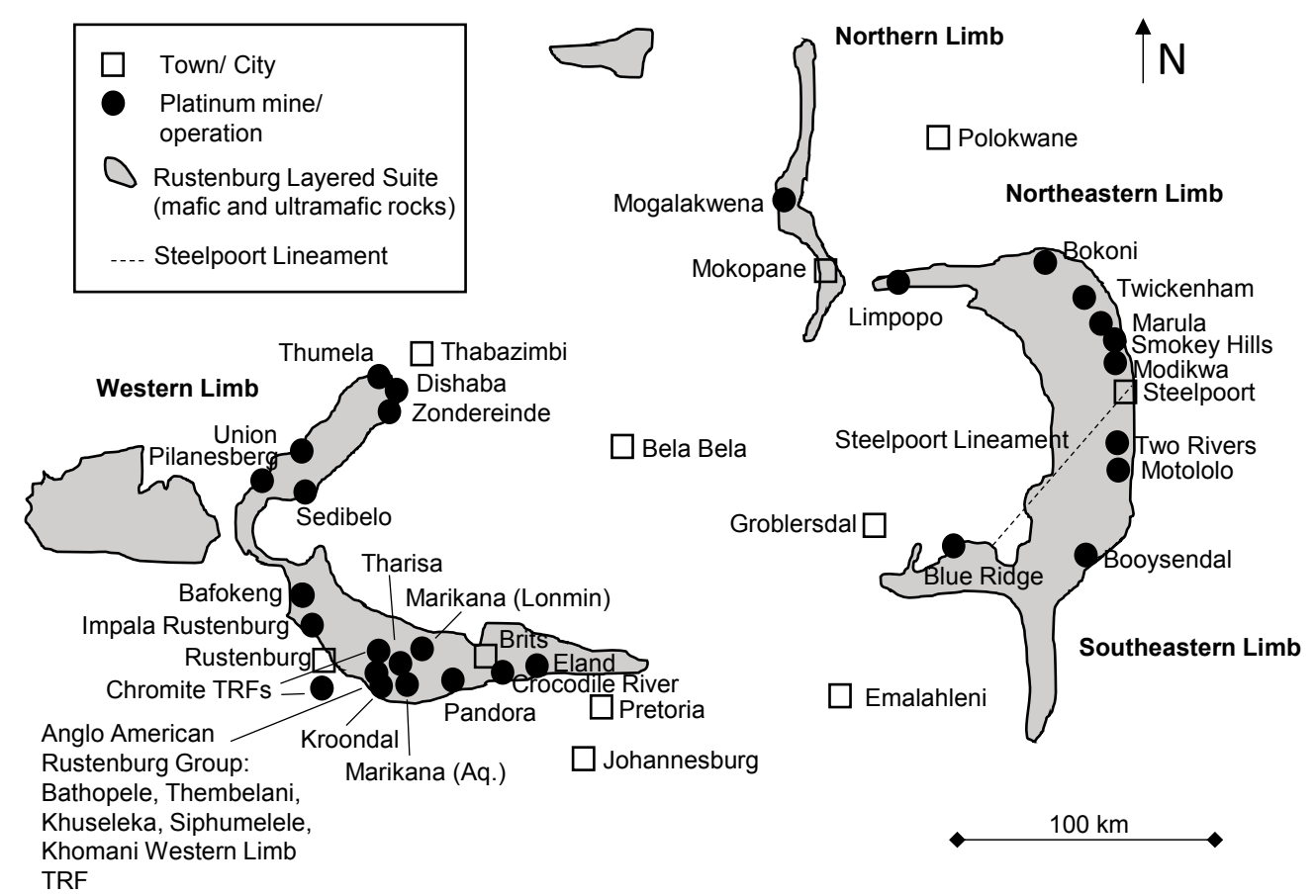

Figure 3. Mines and mine projects in the South African Bushveld Complex.

UG2 chromitite. The UG2 chromitite layer presents the largest known resource of PGE and extends from the Eastern to the Western Limb of the Bushveld complex $[9,45,67]$. The layer is situated between $20 \mathrm{~m}$ and $400 \mathrm{~m}$ below the Merensky reef and is up to $130 \mathrm{~cm}$ thick $[44,66]$. Within the layer, varying chromite mineral chemistry can be observed (e.g., an upward decrease of $\mathrm{Mg}$, increase of $\mathrm{Cr}$ and $\mathrm{TiO}_{2}$ and changes in the $\mathrm{Pt} / \mathrm{Pd}$ ratio) can be observed [68]. The content of $\mathrm{Rh}$ is significantly higher in the UG2 layer than in Merensky or Platreef and the UG2 layer therefore presents the major source of $\mathrm{Rh}$ in the Bushveld Complex. The UG2 layer contains primary magmatic PGE-bearing minerals and minerals that have been modified by secondary processes (e.g., metasomatic processes). In contrast to the Merensky reef, the UG2 layer exhibits the highest concentration of PGEs at the bottom [65]. The PGE-bearing minerals (mostly Pt sulfide, Pt-Pd sulfide, laurite, ferroplatinum, cooperite, braggite, and $\mathrm{Pt}-\mathrm{Rh}-\mathrm{Cu}$ ) and discrete metals $\mathrm{Pd}$, Os and Ir are heterogeneously distributed, resulting in varying concentrations of PGEs in the lateral extent $[44,45]$. These minerals are often found to have formed at the boundary of chromite and sulfide grains, or enclosed in chromite, as in the case of laurite [64]. The UG2 chromitite layer is comprised of chromite (60-90 vol \%), lesser silicate minerals (5-10 vol \%), and plagioclase (1-10 vol \%) and base metal sulfides (<0.1 vol \%) [53,69]. Chalcopyrite, pentlandite and pyrrhotite are the most common base metal sulfides [66]. These sulfides are predominantly enclosed in silicates [66].

Platreef. The Platreef is located at the northern Limb of the Bushveld complex and is around $40 \mathrm{~m}$ thick [44]. The Platreef is typically mined by open pit methods, but this mining approach is limited to a depth of $500 \mathrm{~m}$ to $800 \mathrm{~m}$, even though the Platreef continues at least to a depth of $2 \mathrm{~km}$ [51]. The reef consists of feldspathic pyroxenite and contains base metal sulfides as well as sporadic chromite [64]. Calc-silicates and serpentinisation of pyroxenites are results of the interaction of hot magma and 
lime-rich rocks below the magma chamber [66]. The PGE-bearing minerals that can be found in the Platreef are isoferro platinum, sperrylite, cooperite, merenskyite and metal alloys [44,66]. The ore grade and composition show high variation, in contrast to the Merensky reef and UG2 chromite layer [66]. In the Platreef, Pd, Os and Ir were found to occur within base metal sulfides, whereas Pt-bearing minerals were found close to alteration rims of base metal sulfides or enclosed in quartz, plagioclase, alkali feldspar and clinopyroxene [70].

The Nkomati Nickel Deposit. The Nkomati Nickel Deposit is hosted by the Uitkomst Complex, which is a satellite intrusion of the Bushveld Complex. The deposit is located $50 \mathrm{~km}$ east of the Eastern Limb of the Bushveld Complex and measures about $10 \mathrm{~km}$ by $800 \mathrm{~m}$ [43]. The mafic-ultramafic intrusion is up to $750 \mathrm{~m}$ thick and hosts large quantities of base-metal sulfides containing, $\mathrm{Ni}, \mathrm{Cu}$, $\mathrm{Cr}$ and PGE. PGEs are produced as a valuable by-product from the extraction of $\mathrm{Ni}$ and $\mathrm{Cu}$. The lithostratigraphic units of the Uitkomst Complex are Gabbronite, Upper Pyroxenite, Periotite, Massive Chromitite, Chromititic Peridotite, Lower Peridotite and Basal Gabbro [71]. The first three constitute the Main Group whereas the latter three constitute the Basal Group. Several sulfide ore bodies are located within the lithographic zones: The Basal Mineralized Zone within the Basal Gabbro Unit, the Main Mineralized Zone within the Lower Pyroxenite Unite and an ore body of sulfides within the Chromititic Periodite Unit. Another sulfide-rich ore body (Massive Sulphide Body-MSB) lies underneath the intrusion. The concentration of PGE is highest in the MSB ( $>6 \mathrm{ppm})$, whereas the concentration of PGE is lower in the other zones ( $<1.1 \mathrm{ppm})$ [72]. The major sulfide minerals in the MSB are pyrrhotite, chalcopyrite and pentlandite; the major PGE-bearing minerals are merenskyite, michenerite and sperrylite [71]. PGEs are either found to be enclosed in minerals (mostly in pyrrhotite) or along grain boundaries (mostly pyrrhotite-pyrrhotite, pyrrhotite-magnetite and pyrrhotite-silicate) [73].

\subsection{The Great Dyke}

The Great Dyke is a layered intrusion in Zimbabwe that measures $480 \mathrm{~km}$ in length and about $8 \mathrm{~km}$ in width. The PGE deposit is a Merensky reef-type deposit and it comprises about $8679 \mathrm{t}$ of the global PGE mineral resources [9]. It extends in a North to North-West direction and is composed of the Musengezi, Hartley, Selukwe and Wedza Complexes [74,75]. This intrusion is characterized by extensive, laterally continuous thin layers of mafic (gabbronorite) and ultramafic rocks (dunite, harzburgite and bronzite) [44]. The Great Dyke contains up to 7\% sulfide and the base metal sulfide concentrations decline from the margin to the central axis of the Great Dyke [64]. PGEs occur at two layers, the Lower and Main Sulfide Zones (LSZ and MSZ). The LSZ is characterized by lower ore grades and is located about $30 \mathrm{~m}$ to $80 \mathrm{~m}$ below the MSZ. Currently, PGEs are economically exploited from the MSZ [49].

The Main Sulfide Zone. The MSZ is located a few meters below the transition between the mafic and ultramafic sequences. Several distinctive layers can be found within the MSZ that exhibit varying concentrations of base metals and PGE [49]. The PGE-bearing minerals are Pt, Pd-bismuthotellurides (i.e., moncheite, maslovite and michenerite), sperrylite, cooperite and braggite, and sulfarsenides. The occurrence of these minerals differs locally: in the North chamber, mostly sulfarsenides and arsenides occur (77\% in occurrence number), whereas predominantly bismuthotellurides and sulfides occur (50\%) in the South chamber [75]. Again, the PGE minerals can be found at contact zones of sulfide-sulfide and sulfide-silicate. Oberthür et al. [75] assessed PGEs of the MSZ and found that about two thirds of Pt is hosted in platinum-group minerals, whereas Pd (and other PGEs) are mostly found in other compounds, e.g., Pd in pentlandite. This implies that different metallurgical treatments are needed to achieve high PGE recoveries $[49,75]$. 


\section{Results}

\subsection{Production in Southern Africa}

In Southern Africa, a complex industry manages the extraction of ore and the production of refined PGEs. At present, South Africa has four integrated primary Pt producers: Anglo American Platinum Corporation Ltd. [76], Impala Platinum Holding Ltd. [77], Lonmin Plc. [78], and Northam Platinum Ltd. [79].

The first three companies are the largest producers of platinum in the world [80]. Additionally, numerous smaller companies operate facilities along the overall production chain, such as single mines, concentrators or tailing retreatment facilities (e.g., Aberdeen International Inc. [81], African Rainbow Minerals Ltd. [82], Aquarius Platinum Ltd. [83], Atlatsa Resource Corporation [84], Eastern Platinum Ltd. [85], Glencore plc. [86], Sedibelo Platinum Mines Ltd. [87], Royal Bafokeng Holdings Ltd. [88], Sylvania Platinum Ltd. [89], Tharisa plc. [90]). In general, the facilities can be differentiated into primary PGE mines, chromite tailings recovery and PGE tailings recovery, depending on the primary product being mined or produced. PGEs are often contained in ores with $\mathrm{Ni}$ and $\mathrm{Cu}$ that are simultaneously processed to increase the overall profitability. PGEs can either be the main product of PGE mines or the byproducts of Ni-Cu mines [16]. An overview of the production of PGE in Southern Africa in 2015 by all these companies is given in Table 1 (Data tables for 2010 to 2014 can be found in Tables S3-S7).

Most of the PGE mines under operation in South Africa run at a depth between $500 \mathrm{~m}$ and $2000 \mathrm{~m}$ [91]. Among all the mines, underground mining presents the most common technique, whereas open pit mining accounts for a minor share of production. Nevertheless, the share of open pit mining increased from 23\% to 33\% of processed material from 2010 to 2015.

Mines in the Western section of the Bushveld Complex have a Pt to Pd ratio of two and above, indicating the processing of Merensky ore. In contrast, mines mostly processing UG2 and MSZ deliver a smaller ratio of $\mathrm{Pt}$ to $\mathrm{Pd}$. Furthermore, the processing of Platreef ore yields higher quantities of the base metals $\mathrm{Ni}$ and $\mathrm{Cu}$. For example, the Mogolakwena open-cut mine, located in the Northern Limb, processes the highest quantities of ore and delivers the highest quantities of base metals among all the mines. Still, the total delivered quantity of PGEs is lower than in the other mines (i.e., Marikana (Lonmin), Impala Rustenburg, Kroondal). The latter three mines deliver about one third of the total PGE production in Southern Africa (Figure 4). Compared to this, all other mines only contribute a (very) minor share to the total production. In 2015, several smaller mines were put on care and maintenance, often due to the demanding market environment. Several of these mines were operating between 2010 and 2014 (and before).

The total production of PGEs decreased since 2011 until it started to increase again in 2014 (Figure 5 (Underlying data can be found in Table S8)). At the moment, UG2 presents the dominant ore type that is processed. The change in processing volumes of a specific ore as consequence of a change in total production following the low production in 2014 is the highest in the case of UG2, in absolute terms; the processing of Merensky and UG2 increased by about 12 and 24 Million t/a of material, respectively. This is a 2.5-fold increase in the case of the processing of Merensky ore, whereas the processing of UG2 ore only increased by a factor of 0.5 .

The head grade steadily decreased in recent years in the Great Dyke and remained more or less stable in all sections of the Bushveld Complex (Figure 6). Companies reported head grades either for $6 \mathrm{E}$ and $4 \mathrm{E}$ PGE. The average head grades among all the mines and tailings treatment facilities between 2010 and 2015 were $3.58 \mathrm{~g}$ 6E/t and $3.40 \mathrm{~g} \mathrm{4E/t.} \mathrm{The} \mathrm{data} \mathrm{was} \mathrm{compiled} \mathrm{on} \mathrm{an} \mathrm{individual}$ mine basis and it reflects the processed head grade per mine and the respective production volume (Table 1, Tables S3-S7, S9). Earlier studies report a strongly declining trend over a longer period of time [92]. A declining trend in ore grade will affect the effort required to produce PGEs, production costs, as well as the environmental performance of PGE production (see part II [17]). 


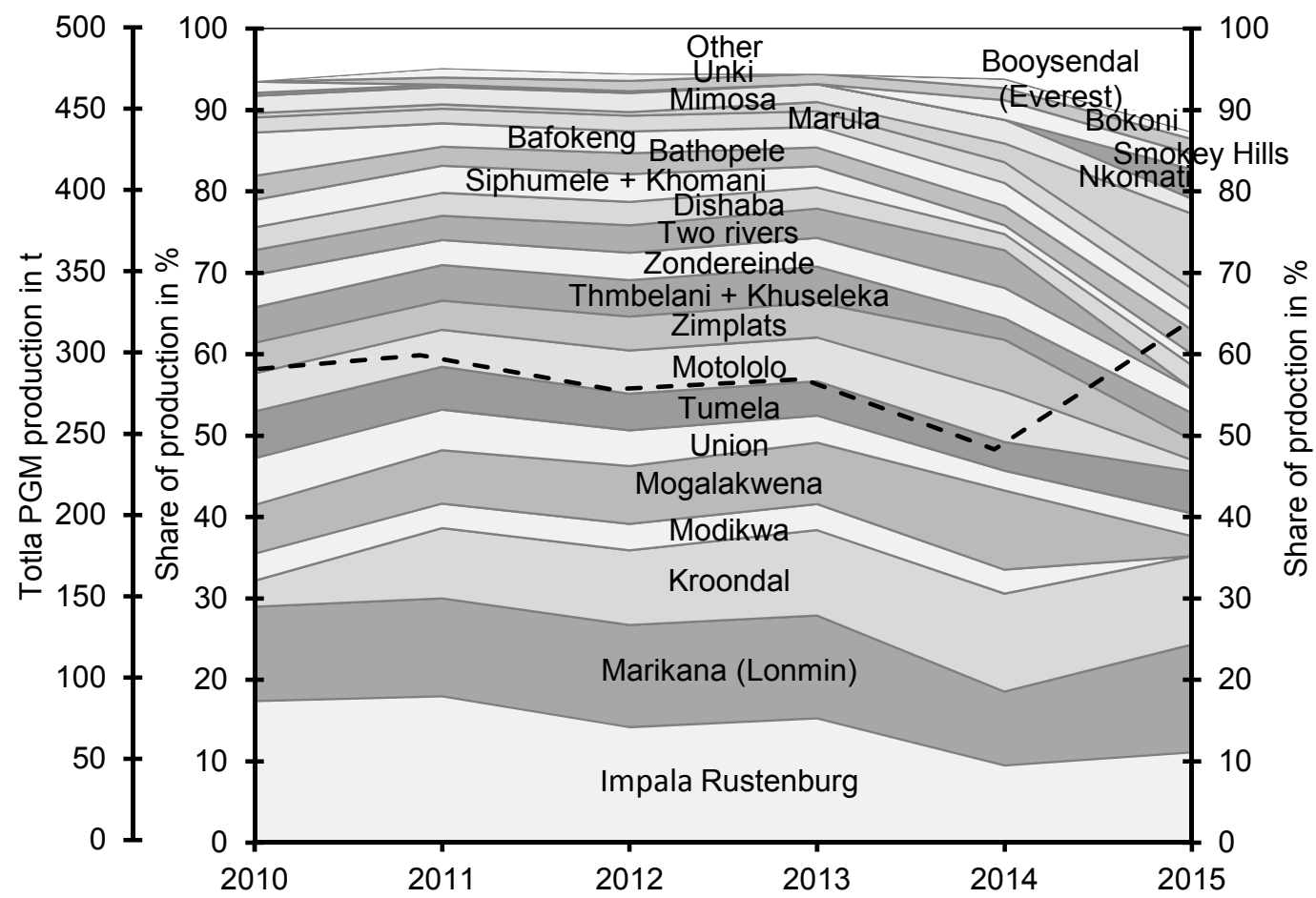

Figure 4. Production shares of different mines and total production (dashed line). Mines specified as "Others" comprise Blue Ridge, Twickenham, Tharisa, Chromite tailings retreatment facility, Eland, Crocodile River, Platinum Mile retreatment facility, Marikana (Aquarius), Pilanesberg, Western Limb Tailings Retreatment, Pandora, Limpopo mines.

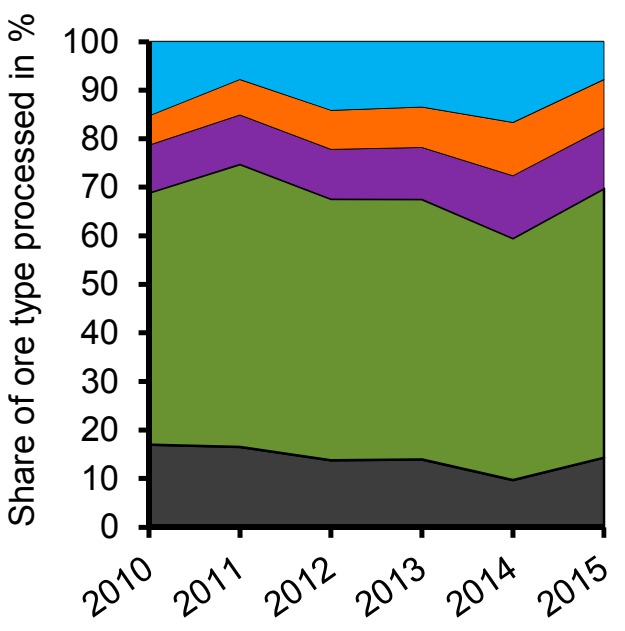

(a)

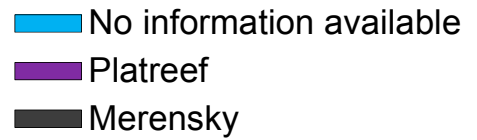

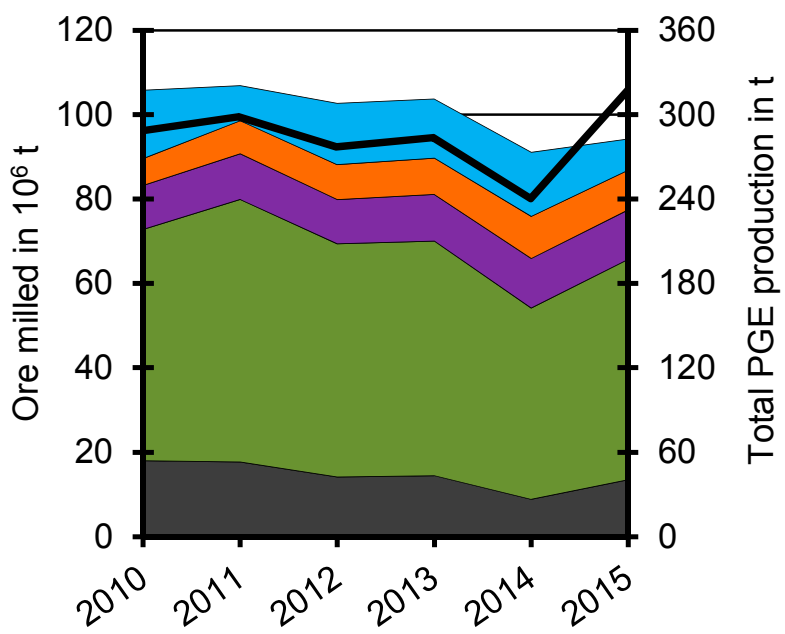

(b)

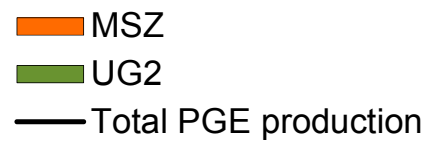

Figure 5. Processed ore types, total 6E PGE production (a) and share of milled ore type (b). 
Table 1. Mining data 2015 [9,24,93-131].

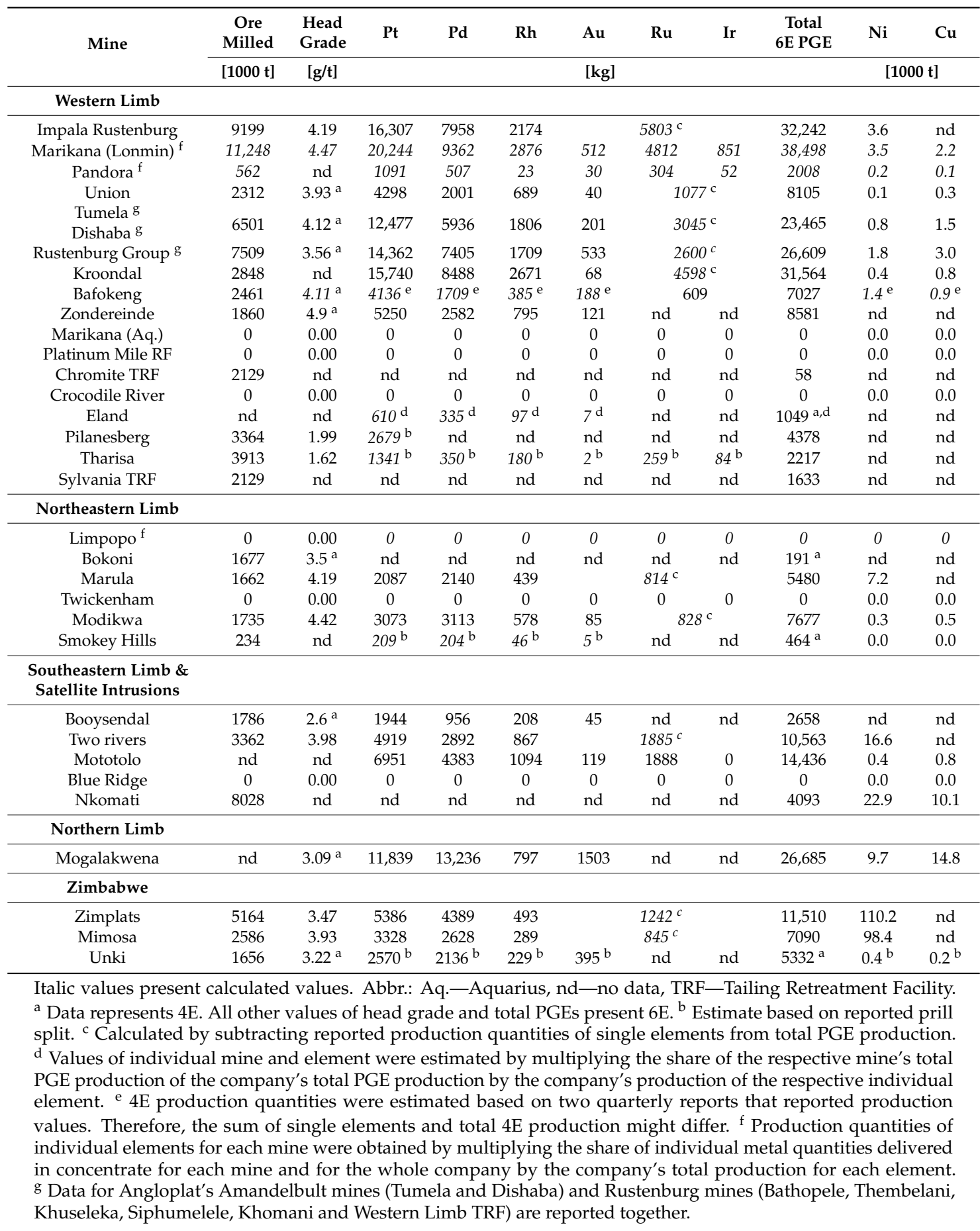



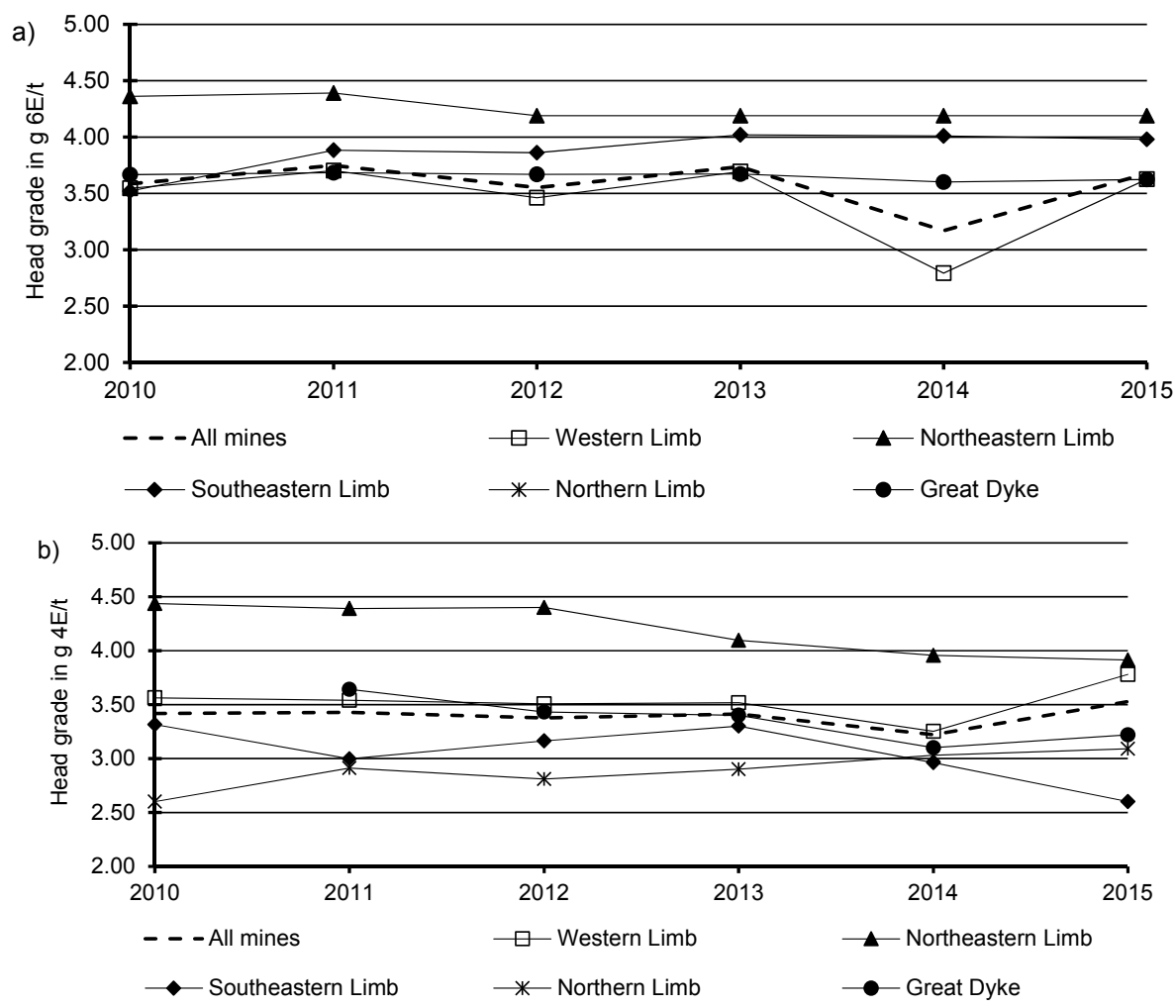

Figure 6. Head grade of processed ore from the Great Dyke and different sections of the Bushveld Complex in $\mathrm{g} 6 \mathrm{E} / \mathrm{t}(\mathbf{a})$ and $\mathrm{g} 4 \mathrm{E} / \mathrm{t}(\mathbf{b})$.

Additionally, production costs are driven by labor costs and the costs of the materials and services required. The costs of mining inputs have increased at a rapid pace in recent years (Figure 7). Labor and energy costs are dependent on national regulations, contracts and agreements, while the prices of diesel and steel follow typically along international markets. From 2008 to 2014, the overall production price index increased by $6.9 \% / a$. In recent years, several strikes affected the South African PGE mining industry, resulting in significant decreases in production and increasing costs.

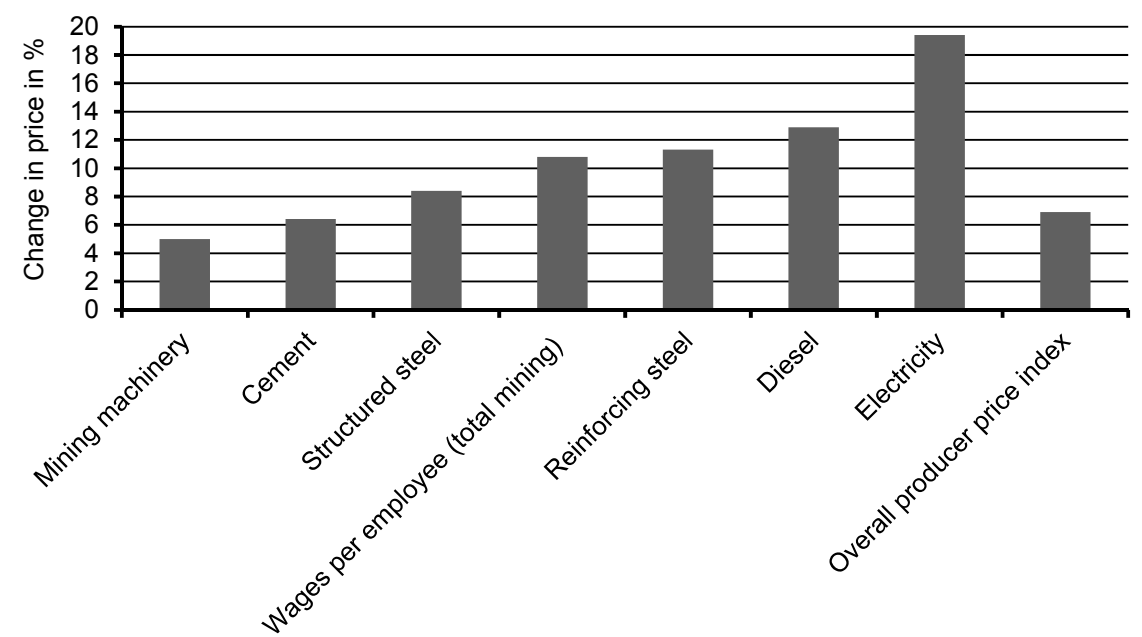

Figure 7. Annual change in costs of mining inputs and the overall producer price index between 2008 and 2014 in South Africa [12]. 


\subsection{Synthesis of Market Data and Production Statistics}

A conflation of marked trends and production data reveals that the basket price of 6E PGE has decreased significantly in recent years (Figure 8). The basket price presents the value of each ton of ore that is hoisted. It is derived from previously presented production data for individual mines, such as ore grades, processed ore types, production quantities, prill splits (Table S2, the market prices for the 4E PGEs; $\mathrm{Ru}$, Ir, and $\mathrm{Cr}$ are not considered in the basket, as prill splits for each reef type at each location are reported in $4 \mathrm{E}$. These minerals only contribute to a minor share of the basket price) and the base metals $\mathrm{Ni}$ and $\mathrm{Cu}$, as well as the exchange rates between US\$ and ZAR. The resulting basket price considers specific ore types from each location in Southern Africa for each year between 2010 and 2015. This synthesis of all previous findings and analyzed data indicates a substantial decrease in the basket prices in US\$ per metric ton of ore. Again, as observed in Figure S1, the price decreases from 2010 to 2015 were alleviated by the exchange rate of US\$ to ZAR: in US\$, the decrease in price amounted to $31 \%$, while the basket price in ZAR increased by $20 \%$.

Base metals present an additional source of revenue from PGE mining. The value of $\mathrm{Ni}$ and $\mathrm{Cu}$ contained in the hoisted ore dropped from 35 to 19 US\$ per ton of ore in 2010 and 2015, respectively. This is due to the decrease in prices of $\mathrm{Ni}$ and $\mathrm{Cu}$ by $45 \%$ and $21 \%$, respectively. The value of $\mathrm{Ni}$ and $\mathrm{Cu}$ accounted for less than $20 \%$ of the total value of each ton of ore, considering base metals and $4 \mathrm{E}$ PGEs in the period from 2010 to 2015.

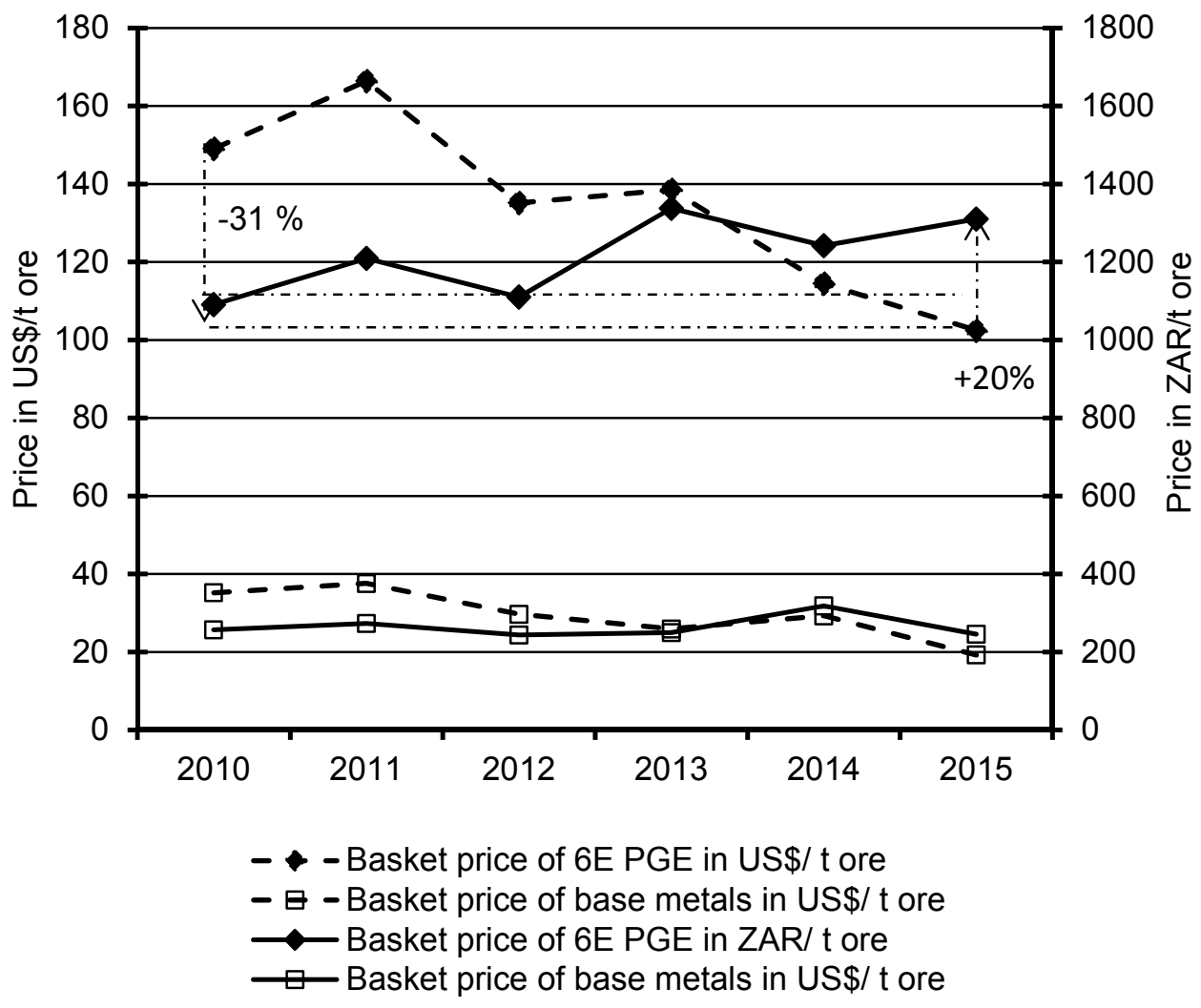

Figure 8. Basket price of 4E PGE ore in US\$ and ZAR. Price data obtained from [37,38,132,133].

\section{Discussion}

The presented data for demand, prices and mining production from 2010 to 2015 provide important insights into recent trends in the PGE production in Southern Africa. The mining data and ore specifications reported predominantly originate from industry sources. The assessed data suggests that the Pt mining industry has faced challenging market conditions in recent years mainly for three reasons: 
1. Unfavorable market conditions. After years of growing demand and increasing price, a peak in price and production was reached. This development was caused by an increase in secondary $\mathrm{Pt}$ and $\mathrm{Pd}$ production (recycling) while the rapid increase in demand that took place in the last decade slowed down due to weakening demand from the automotive industry and jewelry market. As Pt can be substituted (at least to some extent) by Pd in several applications, such as catalysts, a substitution of Pt by Pd is likely to be promoted by the lower price of Pd. In 2015, the situation appeared to improve slightly due to increasing demands for Pt. Still, the price of $\mathrm{Pt}$ in US\$ remains clearly below its peak in 2011. The impact of falling prices was alleviated by the exchange rate of US\$ to ZAR. The weak ZAR is likely to influence the rate of capacity development (at least in the short term). Several factors suggest that the PGE market will be more sensitive to price excursions in the future. One reason is inevitably the high concentration of PGE supply on a single country, i.e., South Africa.

2. In the long-term perspective, declining ore grade and the processing of less favorable UG2 ore. The analysis of data shows stable ore grades in most sections of the Bushveld Complex. Nevertheless, studies report declining ore grades in the long term $[9,92]$. The assessed data furthermore reveals that UG2 presents the most processed ore type, whereas the share of Merensky decreased slightly until 2014. UG2 ore tends to have lower ore grades and the processing of UG2 ore is more complicated due to the high chromite content of the ore, and the required higher smelting temperatures, which requires more energy for processing [50].

3. disruption of production and increase in production costs. The Southern African mining industry faced severe strikes in 2012 and 2014 resulting in the loss of lives, cancelation of thousands of working contracts, increasing costs and a strong decline in production volumes. Apart from loss in production, the disruption of Pt supply might have raised concerns with investors and importing countries $[43,134]$. The increase in production inputs combined with the need of hoisting and processing larger quantities of material will ultimately increase production costs.

These factors resulted in the closure of several less profitable mines. Two aspects will mainly affect the Southern African PGE industry in future:

1. Future PGE demand. The demand for Pt and Pd is strongly dependent on environmental policies in the automotive sector. The demand is likely to increase in the future due to the introduction of automotive exhaust catalysts in many regions of the world and an increasing demand for cars as well as, in the long-term, by a promotion of fuel cell technology, even though it has to be kept in mind that the rise of electric vehicles in China, the United States and Europe might decrease the use of automotive exhaust catalysts (see Section 2.1).

2. The role of secondary PGE production. The increase in demand will eventually increase the importance of secondary Pt and Pd. Currently, only about a quarter of Pt demand is covered by recycling. This share can be expected to increase when higher prices promise higher revenues, with regard to technological improvements in the recycling process and the establishment of an appropriate infrastructure for the collection and treatment of recycling material. Past developments show a steady increase in recycling, which will eventually compete with primary PGE production. A compound annual growth rate (CAGRs) of 2.9 is expected for light duty vehicle production in the upcoming decade [20]. This growth rate exceeds the CAGR of primary PGE production (see Section 2.1). Thus, even considering technical improvements that result in a lower $\mathrm{Pt}$ loading of exhaust gas catalytic converters, recycling is required to fulfil the demand. In the long term, when more fuel-cell-driven vehicles enter the market, recycling rates and available stocks might not be sufficient to follow the increase in demand, unless the share of electric vehicles is capable of filling this gap. As a consequence, primary production will remain an important source of PGEs.

Future estimates of demand, primary production and recycling, based on CAGRs of $0.4,1.7$ and $3.3 \%$ / a for primary production, recycling and demand of Pt, respectively (see Section 2.1), indicate a 
supply gap in the near future (Figure 9). This supply gap will eventually be closed by recycling or primary production, depending on profitability and availability of secondary material. With regards to existing infrastructure, the primary PGE industry is most likely to close the supply gap, provided adequate prices are achieved. Future supply of PGEs will be based upon the four founding pillars: technical, environmental, social and economic aspects, rather than on the latest alone. At present, economic aspects have the major influence on current global PGE production but technological advances, social and political frameworks and environmental conditions and regulations targeting them will highly influence the demand and supply of PGEs.

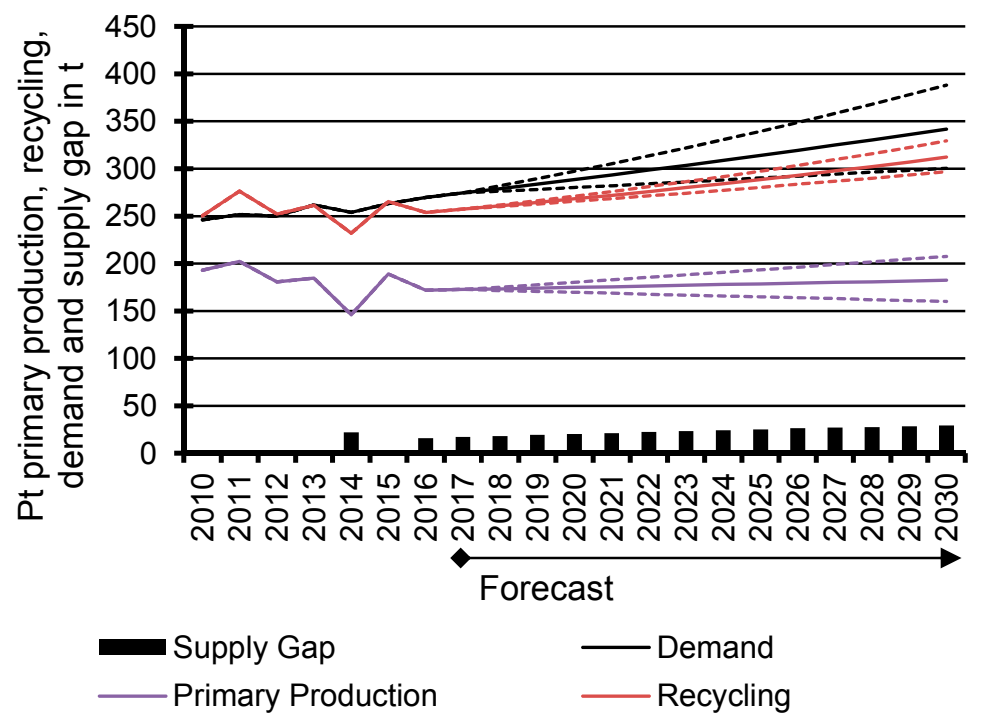

Figure 9. Primary production, recycling, demand and supply gap of Pt from 2010 to 2030. Forecast from 2017 onwards is based on compound annual growth rates (CAGRs) derived from reported estimates by Jolie [15]. Dashed lines present a deviation of the respective CAGR by $\pm 1 \%$-points.

\section{Conclusions}

Southern Africa supplies most of the global PGE demand so far. The assessed data reveal that the Southern African mining industry faces challenging conditions. The combination of increasing costs, tightening market conditions and decreasing ore grades (in the long term) present major challenges that need to be addressed. The data provided in this article, such as production data per mine, as well as ore grades and production volumes can be used for further assessment of the Southern African PGE industry in regards to economic, environmental and social aspects. An assessment of the environmental implications and effects of PGE mining in Southern Africa based on this data is presented in part II of this paper series ([17]).

Supplementary Materials: The following are available online at http:/ / www.mdpi.com/2075-163X/7/11/224/s1, Supplementary Material 1: Table S1: PGE prices in US\$ and ZAR per gram, Table S2: Prill split and base metal content of ores, Table S3: Mining data 2010, Table S4: Mining data 2011, Table S5: Mining data 2012, Table S6: Mining data 2013, Table S7: Mining data 2014, Table S8: Processed ore type in $10^{6} \mathrm{t}$, Table S9: Ore grade in g/t, Figure S1: Pt and Pd price. Prices for 2016 are average values from January to August. Supplementary Material 2: Mine Ownership (Microsoft Excel Sheet).

Acknowledgments: We thank the anonymous reviewers for their contributions that helped to improve this manuscript. This work was supported by the German Federal Ministry of Education and Research under grant number 01DG15004 and by the National Research Foundation of South Africa. This publication was supported by the German Research Foundation (DFG) and the Hamburg University of Technology (TUHH) in the funding programme Open Access Publishing.

Author Contributions: L.T. and B.B. reviewed literature, collected and analyzed data and prepared the manuscript. C.M. and M.K. reviewed the analysis and improved the manuscript. 
Conflicts of Interest: The authors declare no conflict of interest. The founding sponsors had no role in the design of the study; in the collection, analyses, or interpretation of data; in the writing of the manuscript, and in the decision to publish the results.

\section{References}

1. Zientek, M.L.; Loferski, P. Platinum-Group Elements. So Many Excellent Properties. 2014. Available online: http:/ / pubs.usgs.gov/fs/2014/3064/pdf/fs2014-3064.pdf (accessed on 13 November 2016).

2. Crundwell, F.K.; Moats, M.S.; Ramachandran, V.; Robinson, T.G.; Davenport, W.G. Extraction of Platinum-Group Metals from Russian Ores. In Extractive Metallurgy of Nickel, Cobalt and Platinum Group Metals; Elsevier: Amsterdam, The Netherlands, 2011; pp. 429-435.

3. European Commission, DG Enterprise and Industry. Critical Raw Materials for the EU. Report of the AD-Hoc Working Group on Defining Critical Raw Materials; European Commission, DG Enterprise and Industry: Brussels, Belgium, 2010.

4. Hatayama, H.; Tahara, K. Criticality Assessment of Metals for Japan's Resource Strategy. Mater. Trans. 2015, 56, 229. [CrossRef]

5. Ericsson, M.; Tegen, A. Global PGM mining during 40 years: A stable corporate landscape of oligopolistic control. Brief report. Miner. Econ. 2016, 29, 29-36. [CrossRef]

6. Committee on Critical Mineral Impacts on the U.S. Economy, Committee on Earth Resources, Board on Earth Sciences and Resources, Division on Earth and Life Studies, National Research Council of the National Academies. Minerals, Critical Minerals, and the U.S. Economy; The National Academies Press: Washington, DC, USA, 2008.

7. Rao, C.; Reddi, G. Platinum group metals (PGM); occurrence, use and recent trends in their determination. TrAC Trends Anal. Chem. 2000, 19, 565-586. [CrossRef]

8. Naldrett, A.J.; Duke, J.M. Platinum metals magmatic sulfide ores. Science 1980, 208, 1417-1424. [CrossRef] [PubMed]

9. Mudd, G.M. Key trends in the resource sustainability of platinum group elements. Ore Geol. Rev. 2012, 46, 106-117. [CrossRef]

10. Wilburn, D. Global Exploration and Production Capacity for Platinum-Group Metals from 1995 through 2015; U.S. Geological Survey Scientific Investigations Report: Washington, DC, USA, 2012.

11. USGS National Minerals Information Center (Ed.) Mineralbooks 2000-2017. Platinum-Group Metals, 2000-2017. Available online: https://minerals.usgs.gov/minerals/pubs/commodity/platinum/ (accessed on 13 November 2016).

12. Chamber of Mines. Integrated Annual Review 2015; Chamber of Mines: Johannesburg, South Africa, 2015.

13. Chamber of Mines. Overview of the South African Mining Industry. CT Mining Indaba February 2015; Chamber of Mines: Johannesburg, South Africa, 2015.

14. Mudd, G. Platinum group metals: A unique case study in the sustainability of mineral resources. In Proceedings of the 4th International Platinum Conference, Sun City, South Africa, 11-14 October 2010; Southern African Institute of Mining and Metallurgy: Johannesburg, South Africa, 2010; pp. 113-120.

15. Mudd, G.M. Sustainability Reporting and the Platinum Group Metals: A Global Mining Industry Leader? Platin. Met. Rev. 2012, 56, 2-19. [CrossRef]

16. Loferski, P. 2014 Minerals Yearbook; Platinum-Group Metals: Vancouver, BC, Canada, 2014.

17. Buchspies, B.; Thormann, L.; Mbohwa, C.; Kaltschmitt, M. PGE Production in Southern Africa Part II: Environmental Aspects. Minerals 2017, 7, 225.

18. Matthey, J. (Ed.) Summary of Platinum Supply \& Demand in 2015; PGM Market Report; Precious Metals Management: London, UK, 2016. Available online: http:/ / www.platinum.matthey.com/documents/newitem/pgm\%20market\%20reports/pgm-market-report-may-2016.pdf (accessed on 13 November 2016).

19. Robinson, Z. Sustainability of platinum production in South Africa and the dynamics of commodity pricing. Resour. Policy 2017, 51, 107-114. [CrossRef]

20. Jollie, D. Forecasting Platinum Supply and Demand. Available online: https://www.platinuminvestment. com/files/Platinum_Fundamentals_forecast_Glaux_2016.pdf (accessed on 28 June 2017).

21. Alonso, E.; Field, F.R.; Kirchain, R.E. Platinum availability for future automotive technologies. Environ. Sci. Technol. 2012, 46, 12986-12993. [CrossRef] [PubMed] 
22. Matthey, J. (Ed.) Summary of Platinum Supply \& Demand in 2016; PGM Market Report; Precious Metals Management: London, UK, 2017. Available online: http://www.platinum.matthey.com/documents/newitem/pgm\%20market\%20reports/pgm-market-report-may-2016.pdf (accessed on 13 November 2016).

23. Zhang, J.; Everson, M.P.; Wallington, T.J.; Field, F.R., III; Roth, R.; Kirchain, R.E. Assessing Economic Modulation of Future Critical Materials Use: The Case of Automotive-Related Platinum Group Metals. Environ. Sci. Technol. 2016, 50, 7687-7695. [CrossRef] [PubMed]

24. Royal Bafokeng Holdings Ltd. Integrated Report 2015; Royal Bafokeng Holdings Ltd.: Johannesburg, South Africa, 2015.

25. Jollie, D. Overview of PGM Markets. Available online: http://www.angloamerican.com/ / media/ Files / A/Anglo-American-PLC-V2/documents/ platinum-marketing-david-jollie-241116.pdf (accessed on 10 May 2017).

26. European Alternative Fuel Observatory (EAFO). Vehicle Stats. Available online: http://www.eafo.eu/ vehicle-statistics (accessed on 30 August 2017).

27. International Energy Agency (IEA); Organisation for Economic Co-Operation and Development (OECD). Global EV Outlook 2017. Two Million and Counting; IEA Publications: Paris, France, 2017.

28. Weinberg, J.; Kaltschmitt, M.; Schebek, L. Die Zukünftige Entwicklung der Straßengebundenen Mobilität in Deutschland; Kovač: Hamburg, Germany, 2015.

29. Yang, C.-J. An impending platinum crisis and its implications for the future of the automobile. Energy Policy 2009, 37, 1805-1808. [CrossRef]

30. Gather, M.C.; Köhnen, A.; Meerholz, K. White organic light-emitting diodes. Adv.Mater. 2011, 23, $233-248$. [CrossRef] [PubMed]

31. Kappaun, S.; Slugovc, C.; List, E.J. Phosphorescent organic light-emitting devices: Working principle and iridium based emitter materials. Int. J. Mol. Sci. 2008, 9, 1527-1547. [CrossRef] [PubMed]

32. Metalary. Iridium Price. Available online: https://www.metalary.com/iridium-price/ (accessed on 20 February 2016).

33. Ryan, M. PGM Highlights: Platinum in Next-Generation Materials for Data Storage. Platin. Met. Rev. 2010, 54, 244-249. [CrossRef]

34. Nassar, N.T. Limitations to elemental substitution as exemplified by the platinum-group metals. Green Chem. 2015, 17, 2226-2235. [CrossRef]

35. ScotiaMocatta. Precious Metals 2016 Forecast: PGM. Available online: http://www.scotiamocatta.com/ scpt/scotiamocatta/prec/PGM_Forecast_2016.pdf (accessed on 13 February 2017).

36. Couderc, C. Platinum Group Metals in Glass Making. Platin. Met. Rev. 2010, 54, 186-191. [CrossRef]

37. USGS National Minerals Information Center (Ed.) Mineral Commodity Summaries-Nickel, 2017. Available online: https: / / minerals.usgs.gov/minerals / pubs/commodity/nickel/mcs-2017-nicke.pdf (accessed on 25 August 2017).

38. USGS National Minerals Information Center (Ed.) Mineral Comodity Summaries-Copper, 2017. Available online: https://minerals.usgs.gov/minerals/pubs/commodity/copper/mcs-2017-coppe.pdf (accessed on 25 August 2017).

39. Yager, T.; Soto-Viruet, Y.; Barry, J. Recent Strikes in South Africa's Platinum-Group Metal Mines. Effects upon World Platinum-Group Metal Supplies (Open-File Report 2012-1273—ver. 1.1, September 2013); U.S. Geological Survey: Reston, VA, USA, 2013.

40. CPM Group. The CPM Platinum Group Metals Yearbook 2015; CPM Group: Brooklyn, NY, USA, 2015.

41. Matthey, J. (Ed.) Precious Metals Management: Market Data Tables. Available online: http://www.platinum. matthey.com/services/market-research/market-data-tables (accessed on 13 November 2016).

42. Jordaan, J.C. An estimation of the impact of the 2012 platinum-sector strike on the South African economy. $S$. Afr. J. Econ. Manag. Sci. 2016, 19. [CrossRef]

43. Bohlmann, H.R.; van Heerden, J.H.; Dixon, P.B.; Rimmer, M.T. The impact of the 2014 platinum mining strike in South Africa: An economy-wide analysis. Econ. Model. 2015, 51, 403-411. [CrossRef]

44. Haldar, S.K. Deposits of Africa. In Platinum-Nickel-Chromium Deposits; Haldar, S.K., Ed.; Elsevier: Amsterdam, The Netherlands, 2017; pp. 63-96.

45. O’Driscoll, B.; González-Jiménez, J.M. Petrogenesis of the Platinum-Group Minerals. Rev. Mineral. Geochem. 2015, 81, 489-578. [CrossRef] 
46. Fonseca, R.O.; Campbell, I.H.; St. O'Neill, H.C.; Allen, C.M. Solubility of Pt in sulphide mattes: Implications for the genesis of PGE-rich horizons in layered intrusions. Geochim. Cosmochim. Acta 2009, 73, 5764-5777. [CrossRef]

47. Mungall, J.E.; Naldrett, A.J. Ore Deposits of the Platinum-Group Elements. Elements 2008, 4, $253-258$. [CrossRef]

48. Fleet, M.E.; Crocket, J.H.; Stone, W.E. Partitioning of platinum-group elements (Os, Ir, Ru, Pt, Pd) and gold between sulfide liquid and basalt melt. Geochim. Cosmochim. Acta 1996, 60, 2397-2412. [CrossRef]

49. Oberthür, T.; Melcher, F.; Buchholz, P.; Locmelis, M. The oxidized ores of the Main Sulphide Zone, Great Dyke, Zimbabwe: Turning resources into minable reserves-Mineralogy is the key. J. S. Afr. Inst. Min. Metall. 2013, 113, 3 .

50. Gunn, G. Platinum-group metals. In Critical Metals Handbook, 1st ed.; Gunn, G., Ed.; John Wiley \& Sons: Chichester, UK, 2014; pp. 284-311.

51. Cawthorn, R.G. The Platinum Group Element Deposits of the Bushveld Complex in South Africa. Platin. Met. Rev. 2010, 54, 205-215. [CrossRef]

52. Cabri, L.J.; Canadian Institute of Mining, Metallurgy and Petroleum. The Geology, Geochemistry, Mineralogy and Mineral Beneficiation of Platinum-Group Elements; Cabri, L.J., Ed.; Canadian Institute of Mining, Metallurgy and Petroleum: Montreal, CA, USA, 2002.

53. Vermaak, C.F. Platinum-Group Metals. A Global Perspective, 1st ed.; Mintek: Randburg, South Africa, 1995.

54. Bernardis, F.L.; Grant, R.A.; Sherrington, D.C. A review of methods of separation of the platinum-group metals through their chloro-complexes. React. Funct. Polym. 2005, 65, 205-217. [CrossRef]

55. Cawthorn, R. Geological interpretations from the PGE distribution in the Bushveld Merensky and UG2 chromitite reefs: Platinum in transition 'Boom or Bust'. The Southern African Institute of Mining and Metallurgy. In Proceedings of the 4th International Platinum Conference, Sun City, South Africa, 11-14 October 2010; Southern African Institute of Mining and Metallurgy: Johannesburg, South Africa, 2010; pp. 57-70.

56. Zientek, M.L. Magmatic Ore Deposits in Layered Intrusions. Descriptive Model for Reef-Type PGE and Contact-Type Cu-Ni-PGE Deposits. 2012. Available online: https:/ / pubs.usgs.gov/of/2012/1010/contents / OF12-1010.pdf (accessed on 19 November 2016).

57. VonGruenewaldt, G.; Dicks, D.; de Wet, J.; Horsch, H. PGE Mineralization in the Western Sector of the Eastern Bushveld Complex. Mineral. Petrol. 1990, 42, 71-95. [CrossRef]

58. Merkle, R.; Gruenewaldt, G.; von Harney, D. An evaluation of proposed platinum group element contents in the parental magmas of the Bushveld complex. J. Afr. Earth Sci. 1995, 21, 607-613. [CrossRef]

59. Barnes, S.-J.; Maier, W.; Ashwal, L. Platinum-group element distribution in the Main Zone and Upper Zone of the Bushveld Complex, South Africa. Chem. Geol. 2004, 2004, 293-317. [CrossRef]

60. Osbahr, I. Platinum-Group Element Distribution in Base-Metal Sulfides of the Merensky Reef and UG2 from the Eastern and Western Bushveld Complex, South Africa. Ph.D. Thesis, Friedrich-Alexander-Universität Erlangen-Nürnberg, Erlangen-Nürnberg, Germany, 2012.

61. Crundwell, F.K.; Moats, M.S.; Ramachandran, V.; Robinson, T.G.; Davenport, W.G. Platinum-Group Metals, Production, Use and Extraction Costs. In Extractive Metallurgy of Nickel, Cobalt and Platinum Group Metals, 1st ed.; Crundwell, F., Moats, M., Ramachandran, V., Robinson, T., Davenport, W.G., Eds.; Elsevier: Amsterdam, The Netherlands, 2011; pp. 395-409.

62. Naldrett, A.J. Platinum group element (PGE) deposits. In Magmatic Sulfide Deposits; Naldrett, A.J., Ed.; Springer: Berlin/Heidelberg, Germany, 2004; pp. 481-612.

63. Cawthorn, R.G.; Lee, C.A.; Schouwstra, R.P.; Mellowship, P. Relationship between PGE and PGM in the Bushveld Complex. Can. Mineral. 2002, 40, 311-328. [CrossRef]

64. Lee, C.A. A Review of Mineralization in the Bushveld Complex and some other Layered Intrusions. In Layered Intrusions; Cawthorn, R.G., Ed.; Elsevier: Amsterdam, The Netherlands, 1996; pp. 103-145.

65. Rose, D.; Viljoen, F.; Knoper, M.; Rajesh, H. Detailed assessment of Platinum-Group Minerals associated with the chromitite stringers in the Merensky reef of the Eastern Bushveld Complex, South Africa. Can. Mineral. 2012, 49, 1385-1396. [CrossRef]

66. Schouwstra, R.P.; Kinloch, E.D.; Lee, C.A. A short geological review of the Bushveld Complex. Platin. Met. Rev. 2000, 44, 33-39. 
67. Mondal, S.K.; Mathez, E.A. Origin of the UG2 chromitite layer, Bushveld Complex. J. Petrol. 2007, 48, 495-510. [CrossRef]

68. Junge, M.; Oberthur, T.; Melcher, F. Cryptic variations of chromite chemistry, Platinum Group Element and Platinum Group Mineral distribution in the UG-2 chromitite: An example from the Karee Mine, Western Bushveld Complex, South Africa. Econ. Geol. 2014, 109, 795-810. [CrossRef]

69. Voordouw, R.J.; Beukes, N.J. Alteration and metasomatism of the UG2 melanorite and its stratiformpegmatoids, Bushveld Complex, South Africa-characteristics, timing and origins. S. Afr. J. Geol. 2009, 112, 47-64. [CrossRef]

70. Hutchinson, D.; McDonald, I. Laser ablation ICP-MS study of platinum-group elements in sulphides from the Platreef at Turfspruit, northern limb of the Bushveld Complex, South Africa. Min. Depos. 2008, 43, 695-711. [CrossRef]

71. Theart, H.; de Nooy, C.D. The Platinum Group Minerals in two parts of the Massive Sulphide Body of the Uitkomst Complex, Mpumalanga, South Africa. S. Afr. J. Geol. 2001, 104, 287-300. [CrossRef]

72. Maier, W.D.; Gomwe, T.; Barnes, S.-J.; Li, C.; Theart, H. Platinum Group Elements in the Uitkomst Complex, South Africa. Econ. Geol. 2004, 99, 499-516. [CrossRef]

73. Hutchinson, D.; Kinnaird, J.A. Complex multistage genesis for the Ni-Cu-PGE mineralisation in the southern region of the Platreef, Bushveld Complex, South Africa. Appl. Earth Sci. 2013, 114, 208-224. [CrossRef]

74. Wilson, A. The Geology of the Great 'Dyke', Zimbabwe: The Ultramafic Rocks. J. Petrol. 1982, 23, $240-292$. [CrossRef]

75. Oberthür, T. Platinum-group element mineralization of the main sulfide zone, Great Dyke, Zimbabwe. Rev. Econ. Geol. 2011, 17, 329-349.

76. Anglo American Platinum Ltd. Available online: http://www.angloamericanplatinum.com/ (accessed on 10 May 2017).

77. Impala Platinum Holdings Ltd. Available online: http://www.implats.co.za/implats/index.asp (accessed on 10 May 2017).

78. Lonmin Plc. Available online: https:/ / www.lonmin.com/ (accessed on 10 May 2017).

79. Northam Platinum Ltd. Available online: http:/ / www.northam.co.za/ (accessed on 10 May 2017).

80. Jones, R. An overview of Southern African PGM Smelting, Nickel and Cobalt 2005: Challenges in Extraction and Production. In Proceedings of the Annual Conference of Metallurgists, Calgary, CA, Canada, 21-24 August 2005; Canadian Institute of Mining, Metallurgy and Petroleum: Westmount, CA, Canada, 2005; pp. 147-178.

81. Aberdeen International Inc. Available online: http://www.aberdeeninternational.ca/ (accessed on 10 May 2017).

82. African Rainbow Minerals Ltd. Available online: http://www.arm.co.za/ (accessed on 10 May 2017).

83. Aquarius Platinum Ltd. Available online: http:/ / www.aquariusplatinum.com/ (accessed on 10 May 2017).

84. Atlatsa. Available online: www.atlatsaresources.co.za (accessed on 8 January 2016).

85. Eastern Platinum Ltd. Available online: http:/ / www.eastplats.com/ (accessed on 10 May 2017).

86. Glencore Plc. Available online: http:/ / www.glencore.com/ (accessed on 10 May 2017).

87. Sedibelo Platinum Mines Ltd. Available online: www.sedibeloplatinum.com (accessed on 10 May 2017).

88. Royal Bafokeng Holdings Ltd. Available online: http://www.bafokengholdings.com/ (accessed on 10 May 2017).

89. Sylvania resources Ltd. Available online: www.sylvaniaplatinum.com (accessed on 10 May 2017).

90. Tharisa Plc. Available online: www.tharisa.com/ (accessed on 10 May 2017).

91. Platinum Group Metals Association. The Primary Production of Platinum Group Metals (PGMs); Platinum Group Metals Association: Munich, Germany, 2015.

92. Glaister, B.J.; Mudd, G.M. The environmental costs of platinum-PGM mining and sustainability: Is the glass half-full or half-empty? Miner. Eng. 2010, 23, 438-450. [CrossRef]

93. Aberdeen International Inc. A Technical Report on the Smokey Hills Platinum Mine, Limpopo Province, South Africa; Aberdeen International Inc.: Roodepoort, South Africa, 2016.

94. Aberdeen International Inc. African Thunder Platinum: A Platinum/Palladium Producer in South Africa. Available online: http:/ / www.aberdeeninternational.ca/Portfolio/Proven-Track-Record/Proven-TrackRecord/2010/Avion/default.aspx (accessed on 18 November 2016). 
95. Anglo American Platinum Ltd. (Ed.) Operations Review 2014; Anglo American Platinum Ltd.: Johannesburg, South Africa, 2014.

96. Anglo American Platinum Ltd. (Ed.) Fact Book 2015. Focus: Operating Smarter; Anglo American Platinum Ltd.: Johannesburg, South Africa, 2015.

97. Anglo American Platinum Ltd. (Ed.) Quarterly Production Report; Anglo American Platinum Ltd.: Johannesburg, South Africa, 2016.

98. Aquarius Platinum Ltd. (Ed.) Annual Reports 2010; Aquarius Platinum Ltd.: Johannesburg, South Africa, 2010.

99. Eastern Platinum Ltd. (Ed.) Sustainable Development Report 2010; Eastern Platinum Ltd.: Bryanston, South Africa, 2010.

100. Eastern Platinum Ltd. (Ed.) Quarterly reports 2011-2012; Eastern Platinum Ltd.: Bryanston, South Africa, 2011-2012.

101. Impala Platinum Holdings Ltd. (Ed.) Integrated Annual Report 2014; Impala Platinum Holdings Ltd.: Illovo, South Africa, 2014.

102. Impala Platinum Holdings Ltd. (Ed.) Annual Integrated Report 2016; Impala Platinum Holdings Ltd.: Illovo, South Africa, 2016.

103. Lonmin Plc. (Ed.) Annual Report and Accounts. Building for Future; Lonmin Plc.: London, UK, 2011.

104. Lonmin Plc. (Ed.) Operating Statistics: Five Year Review. Available online: http://www.lonmin.com/ reports/2015/online_annual_report_2015/a_deeper_look/operating_statistics_five_year_review_01.html (accessed on 18 November 2016).

105. Northam Platinum Ltd. (Ed.) Annual Integrated Report 2014; Northam Platinum Ltd.: Johannesburg, South Africa, 2014.

106. Northam Platinum Ltd. (Ed.) Annual Integrated Report 2016; Northam Platinum Ltd.: Johannesburg, South Africa, 2016.

107. Platmin Ltd. (Ed.) Annual Report for the Year Ended December 31, 2010; Platmin Ltd.: Centurion, South Africa, 2011.

108. Royal Bafokeng Holdings Ltd. (Ed.) Quarterly Review and Production Report for the Period 1 January 2012 to 30 September 2015; Royal Bafokeng Holdings Ltd.: Johannesburg, South Africa, 2012-2015.

109. Sedibelo Platinum Mines Ltd. (Ed.) Management's Discussion and Analysis of Financial Condition and Results of Operations for the Three and Twelve Months Ended December 31, 2012; Sedibelo Platinum Mines Ltd.: Highveld, South Africa, 2013. Available online: http://www.sedibeloplatinum.com/downloads/send/49-2013/ 216-management-s-discussion-and-analysis-for-the-three-and-twelve-months-ended-december-31-2012 (accessed on 18 November 2016).

110. Sedibelo Platinum Mines Ltd. (Ed.) Consolidated and Separate Financial Statements for the Year Ended December 31, 2013; Sedibelo Platinum Mines Ltd.: Highveld, South Africa, 2014. Available online: http: / / www.sedibeloplatinum.com/downloads/send/4-2014/121-consolidated-financialstatements-for-the-year-ended-december-31-2013 (accessed on 18 November 2016).

111. Sedibelo Platinum Mines Ltd. (Ed.) Management's Discussion and Analysis of Financial Condition and Results of Operations for the Three and Twelve Months Ended December 31, 2014; Sedibelo Platinum Mines Ltd.: Highveld, South Africa, 2015. Available online: http:/ / www.sedibeloplatinum.com/component/jdownloads/send/ 48-2014/273-platmin-mda-31-dec-2014 (accessed on 18 November 2016).

112. Sedibelo Platinum Mines Ltd. (Ed.) Management's Discussion and Analysis of Financial Condition and Results of Operations for the Three and Twelve Months Ended December 31, 2015; Sedibelo Platinum Mines Ltd.: Highveld, South Africa, 2016. Available online: http:/ / www.sedibeloplatinum.com/component/jdownloads/send/ 44-2015/279-management-s-discussion-and-analysis-of-financial-condition-and-results-of-operationsfor-the-three-and-twelve-months-ended-december-31-2015 (accessed on 18 November 2016).

113. Sylvania Resources Ltd. (Ed.) Annual Report 2011; Sylvania resources Ltd.: Hamilton, Bermuda, 2011.

114. Sylvania Resources Ltd. (Ed.) Annual Report 2013; Sylvania resources Ltd.: Hamilton, Bermuda, 2013.

115. Sylvania Resources Ltd. (Ed.) Annual Report 2015; Sylvania resources Ltd.: Hamilton, Bermuda, 2015.

116. Tharisa Plc. (Ed.) Annual Report 2014; Tharisa Plc.: Paphos, Cyprus, 2015.

117. Tharisa Plc. (Ed.) Annual Report 2015; Tharisa Plc.: Paphos, Cyprus, 2016.

118. Xstrata Plc. (Ed.) Mineral Resources \& Ore Reserves 2011; Xstrata Plc.: Zug, Switzerland, 2011.

119. Xstrata Plc. (Ed.) Mineral Resources \& Ore Reserves 2012; Xstrata Plc.: Zug, Switzerland, 2012. 
120. African Rainbow Minerals Ltd. (Ed.) Integrated Annual Report 2015; African Rainbow Minerals Ltd.: Sandton, South Africa, 2015.

121. African Rainbow Minerals Ltd. (Ed.) Integrated Annual Report 2010; African Rainbow Minerals Ltd.: Sandton, South Africa, 2010.

122. African Rainbow Minerals Ltd. (Ed.) Integrated Annual Report 2011; African Rainbow Minerals Ltd.: Sandton, South Africa, 2011.

123. African Rainbow Minerals Ltd. (Ed.) Integrated Annual Report 2012; African Rainbow Minerals Ltd.: Sandton, South Africa, 2012.

124. African Rainbow Minerals Ltd. (Ed.) Integrated Annual Report 2013; African Rainbow Minerals Ltd.: Sandton, South Africa, 2013.

125. African Rainbow Minerals Ltd. (Ed.) Integrated Annual Report 2014; African Rainbow Minerals Ltd.: Sandton, South Africa, 2014.

126. Glencore Plc. (Ed.) Production Report for the 12 Months Ended 31 December 2015.2016. Available online: http:/ / www.glencore.com/assets/investors/doc/reports_and_results/2015/GLEN-2015Q4-Production-Report.pdf (accessed on 20 November 2016).

127. Aquarius Platinum Ltd. (Ed.) Annual Report 2011; Aquarius Platinum Ltd.: Johannesburg, South Africa, 2011.

128. Aquarius Platinum Ltd. (Ed.) Annual Report 2012; Aquarius Platinum Ltd.: Johannesburg, South Africa, 2012.

129. Aquarius Platinum Ltd. (Ed.) Annual Report 2013; Aquarius Platinum Ltd.: Johannesburg, South Africa, 2013.

130. Aquarius Platinum Ltd. (Ed.) Annual Report 2014; Aquarius Platinum Ltd.: Johannesburg, South Africa, 2014.

131. Aquarius Platinum Ltd. (Ed.) Annual Report 2015; Aquarius Platinum Ltd.: Johannesburg, South Africa, 2015.

132. USGS National Minerals Information Center (Ed.) Mineralbooks 1998-2016. Gold, 2016. Available online: https: / / minerals.usgs.gov/minerals / pubs/commodity/gold/ (accessed on 13 November 2016).

133. USGS National Minerals Information Center (Ed.) Mineralbooks 1998-2016. Platinum-Group Metals, 2016. Available online: https:/ / minerals.usgs.gov/minerals/pubs/commodity/platinum/ (accessed on 13 November 2016).

134. European Parliament. Resolution on South Africa: Massacre of Striking Miners. Resolution 2012/2783(RSP); European Parliament: Brussels, Belgium; Strasbourg, France, 2012.

(C) 2017 by the authors. Licensee MDPI, Basel, Switzerland. This article is an open access article distributed under the terms and conditions of the Creative Commons Attribution (CC BY) license (http:/ / creativecommons.org/licenses/by/4.0/). 